\title{
Colorectal Cancer and Probiotics: Are Bugs Really Drugs? ${ }^{\dagger}$
}

\author{
Purushottam Lamichhane ${ }^{1}$, Morgan Maiolini ${ }^{2}$, Omar Alnafoosi ${ }^{2}$, Sedra Hussein ${ }^{3}$, \\ Hasan Alnafoosi ${ }^{2}$, Stewart Umbela ${ }^{2}$, Tayanna Richardson ${ }^{2}$, Nevien Alla ${ }^{2}$, \\ Narottam Lamichhane ${ }^{4}$, Bobban Subhadra ${ }^{5}$ and Rahul R. Deshmukh ${ }^{2, *(D)}$ \\ 1 LECOM School of Dental Medicine, 4800 Lakewood Ranch Blvd, Bradenton, FL 34211, USA; \\ plamichhane@lecom.edu \\ 2 LECOM School of Pharmacy, 5000 Lakewood Ranch Blvd, Bradenton, FL 34211, USA; \\ MMaiolini21274@rx.lecom.edu (M.M.); OAlnafoosi79536@rx.lecom.edu (O.A.); \\ HAlnafoosi89566@rx.lecom.edu (H.A.); Stewart.Umbela@rx.lecom.edu (S.U.); trichardson@lecom.edu (T.R.); \\ NAlla92956@rx.lecom.edu (N.A.) \\ 3 Upstate Medical University, 750 East Adams Street, Syracuse, NY 13210, USA; Husseins@upstate.edu \\ 4 Department of Radiation Oncology, University of Maryland School of Medicine, Baltimore, MD 21201, USA; \\ NaruLamichhane@umm.edu \\ 5 BIOM Pharmaceuticals, 2203 Industrial Blvd, Sarasota, FL 34234, USA; bbobban@gmail.com \\ * Correspondence: rdeshmukh@lecom.edu \\ + This review is dedicated to the memory of our wonderful colleague, Prof. Dr. Kenneth S. Bauer Jr., PharmD, \\ Ph.D.
}

Received: 10 March 2020; Accepted: 23 March 2020; Published: 5 May 2020

\begin{abstract}
Colorectal cancer (CRC) is one of the most common types of cancer worldwide. There are many factors that predispose a patient to the disease such as age, family history, ethnicity, and lifestyle. There are different genetic factors and diseases that also increase a person's risk for developing CRC. Studies have found associations between gut microbiome and the risk for developing versus protection against CRC. Normal gut microbiome aid in daily functions of the human body such as absorption, metabolism, detoxification, and regulation of inflammation. While some species of bacteria prevent CRC development and aid in therapeutic responses to various treatment regiments, other species seem to promote CRC pathogenesis. In this regard, many studies have been conducted to not only understand the biology behind these opposing different bacterial species; but also to determine if supplementation of these tumor opposing bacterial species as probiotics lends toward decreased risk of CRC development and improved therapeutic responses in patients with CRC. In this literature review, we aim to discuss the basics on colorectal cancer (epidemiology, risk factors, targets, treatments), discuss associations between different bacterial strains and CRC, and discuss probiotics and their roles in CRC prevention and treatment.
\end{abstract}

Keywords: colorectal cancer; chemoprevention; probiotics; gut microflora; bacteria

\section{Introduction}

\subsection{Epidemiology}

Colorectal cancer (CRC) is the third most commonly diagnosed cancer, excluding skin cancer, and the third most deadly cancer in the United States [1]. The estimated new cases for 2020 are 147,950 and it is estimated to cause close to 53,200 deaths in both genders in 2020 [2]. Fortunately, the incidence of colorectal cancer has steadily declined from 53.3 per 100,000 individuals in 2000 to 35.7 per 100,000 individuals in 2017. At the same time period, the death rate from this cancer has modestly declined 
from 20.7 to 13.5 deaths per 100,000 individuals [2]. The 5-year survival, however, has remained unchanged at $65.0 \%$ in 2000 and $65.7 \%$ in 2012, with the cumulative rate of $64.6 \%$ from 2010-2016 [2]. Additionally, while incidence of colorectal cancer has declined in individuals older than 50 years from 2009 to 2013, it has increased in individuals younger than 50 years old. The death rates, however, have decreased in adults younger than 50 years old, while they have increased in individuals older than 50 years of age. Currently, it is not completely understood why these trends are occurring [3,4].

Incidence of CRC also varies between different ethnic groups and socioeconomic status. Lower socioeconomic status has been found to be associated with a higher prevalence of risk factors for CRC such as obesity, smoking, and unhealthy diet. Additionally, patients with lower socioeconomic status may have inadequate access or affordable access to screening methods and early treatments [4]. There are also geographical disparities in the incidence rates of CRC. In the USA, it is more prevalent in Southern and Midwestern states. This is both due to the difference in demographics, but also other localized factors such as laws/regulations, travel distances to access medical services, and socioeconomic issues [4]. The breakdown of statistics, trends in incidences and mortality, and relative risks for CRC are well documented in detail by the American Cancer Society in its "Colorectal Cancer Facts \& Figures 2017-2019" document [4]. Globally, the distribution also has variations. In Northern and Western Europe, rates of colon cancer have been stabilizing. However, Japan, Singapore, and Eastern Europe have seen rapidly increasing rates of colon cancer since the 1970s. Rates of colon cancer have always traditionally been lowest in Africa and other low-income regions of the world [5].

Incidence of right-sided (proximal colon) colon tumors has increased over the past decade while the incidence of left-sided (distal) colon tumors has decreased [6]. Right-sided colon cancer is when the neoplasm is found in the cecum and ascending colon up to the hepatic flexure. Left-sided colon cancer is in the splenic flexure or surrounding including the rectum [6]. This can be explained by the fact that screening is better at detecting left-sided tumors compared to right-sided ones. This is due to the development, location, and morphology of the tumor growths. Routine screenings, and removal of adenomatous polyps, when found, have decreased the incidence of left-sided colon cancer significantly. In addition to difficulty in detecting, right-sided tumors are also more difficult to treat due to region of growth and a greater number of genetic mutations; these tumors, however, seem to respond better to immunotherapies (including but not limited to ipilimumab, tremelimumab, nivolumab) [7].

\subsection{Colon Cancer}

\subsubsection{Risk Factors and Potential Causes of Colon Cancer Carcinogenesis}

There does not appear to be any specific, single known cause of colorectal cancer. There are numerous risk factors that are linked to the development of colorectal cancer. The mechanisms by which these risk factors cause colorectal cancer carcinogenesis are poorly understood. Lynch Syndrome and familial adenomatous polyposis are perhaps the only exceptions to this rule as they are genetic conditions, but they do not account for the majority of colorectal cancer incidence globally $[3,4]$. Keeping this in mind, the following list is an overview of some of the most prominent risk factors and the associated mechanisms for the development of colorectal cancer:

\section{Bacteria}

Certain bacterial strains and dysbiosis of gut microbiota have been associated with the development of colorectal cancer. Species such as Enterococcus faecalis, Shigella, Bacteroides fragilis, and more can produce toxins and superoxide (SO) agents; and increase host inflammatory responses; hence driving the process of colorectal carcinogenesis [8]. Increased abundance of enterotoxigenic Bacteroides fragilis (ETBF) has been found in early-stage lesions of colorectal neoplasia [9] and stool samples from colorectal cancer patients [10]. Additionally, exposure of colon mucosa to Bacteroides fragilis toxins has been suggested to be a risk factor for CRC development [11]. Elsewhere, Chung et al. showed that $B$. fragilis 
toxin drives tumorigenesis of colonic epithelial cells through mechanisms that are dependent on interleukin-17 (IL-17) and signal-transducer-and-activator-of-transcription 3 (STAT3) activity [12]. In one preclinical study, however, Lee et al. showed that $B$. fragilis colonization protected mice from colitis-associated CRC through a mechanism dependent on polysaccharide A production and toll-like receptor 2 (TLR2) signaling and associated with inhibition of $\mathrm{C}-\mathrm{C}$ motif chemokine receptor 5 (CCR5) in the colon [13]. Streptococcus bovis, specifically Streptococcus gallolyticus, is another bacterium that correlates with increased rates of CRC [14]. It has been shown that Streptococcus gallolyticus may promote inflammation-driven development or progression of CRC through mechanisms dependent, in part, on interleukin-1 (IL-1), interleukin-8 (IL-8), and cyclooxygenase 2 (COX-2) signals [14,15]. In the analysis of colorectal cancer tissues, it was identified that $S$. bovis/gallolyticus promotes colorectal carcinogenesis through inflammatory mechanisms dependent, in part, on IL-1, IL-8, and COX-2 signals [14]. In a model of azoxymethane-treated rats, cell wall components from Streptococcus bovis were shown to promote pre-neoplastic lesions through mechanisms dependent on IL-8 and COX-2, and the activation of MAPK signals [15]. Many other bacterial strains such as Enterococcus faecalis, Shigella, and Escherichia coli (NC101) have also been shown to drive CRC development [8]. Fusobacterium nucleatum is another bacterium whose concentrations in tissue and feces is found at higher levels at later stages of CRC [16]. F. nucleatum mediated promotion of CRC may involve FadA adhesion mediated modulation of E-cadherin/ $\beta$-catenin signaling [17] and Fap2 binding to inhibitory receptor TIGIT (T cell immunoreceptor with Ig and ITIM domains) and subsequent inhibition of NK cell mediated cytotoxicity and T-cell activity [18]. Additional mechanisms of F. nucleatum mediated colorectal carcinogenesis have been reviewed by Shang and Liu [19]. Some of these mechanisms include miR-21 expression, hyperactivation of NF- $\mathrm{kB}$, suppression of T-cell activity, and attraction of myeloid derived suppressor cells (MDSCs) [19]. It is generally agreed that bacterial causes to CRC are normally due to a variety of species rather than a solo bacterium [19-21]. Some of the bacteria and mechanisms associated with CRC or promotion of CRC are summarized in Table 1.

\section{Bacteria and Protection against Colorectal Cancer}

While it is evident that some bacteria associate with or drive CRC development and progression, others may have a protective role; hence highlighting the role of dysbiosis in CRC. Lactic acid producing bacteria (LAB) have been shown to confer protection against CRC [22]. Bifidobacterium, a LAB and part of normal human microflora, has been reported to have anti-tumor properties [23]. In a human study, it was found that intake of yogurt containing Bifidobacterium longum resulted in increased amounts of short-chain fatty acids (SCFAs) and decreased Bacteroides fragilis enterotoxin in feces. The same study showed that short-chain fatty acids such as butyric acid, isobutyric acid, and acetic acid had growth inhibitory activity against colon cancer cell lines in vitro [24]. Animal studies have also shown benefits of different bacteria. Mechanisms by which bacteria confer protection against CRC include competition against pathogenic bacteria, metabolic functions, and genetic modulations [22]. In a colitis-induced murine model of CRC, administration of Bifidobacterium longum resulted in increased expression of tumor suppressor micro-RNAs (miRs) miR-145, and miR-15a, decreased expression of miR-146a (which regulates expression of interleukins $1 \beta$ and 6), decreased nuclear factor kappa-light-chain-enhancer of activated B cell (NF-KB) activation, and resulted in decreased aberrant crypt foci numbers [25]. In another murine study, Bifidobacterium longum has also been reported to suppress food mutagen (2-Amino-3-methylimidazo(4,5-f)quinoline) induced colon cancer incidence [26]. Many other LABs have been shown to have protective roles against CRC. These include Lactobacillus acidophilus, Streptococcus thermophilus, Lactobacillus casei, Lactobacillus salivarius, Lactobacillus plantarum, and Lactobacillus rhamnosus [22,27]. Mechanisms of inhibition of CRC initiation and progression employed by LAB include induction of apoptosis of tumor cells, metabolic antioxidant activity, activation of anti-tumor immune effectors, and anti-tumorigenic epigenetic modifications through metabolic products such as SCFAs [22,27]. Some of the bacteria and mechanisms associated with CRC or promotion of CRC are summarized in Table 2. 
In the context of immunotherapy, some bacterial species such as Bifidobacterium have been shown to promote anti-tumor immunity and also correlate with the efficacy of programmed death ligand-1 (PD-L1) checkpoint blockade [28]. Interestingly, B. fragilis, which is shown to promote CRC carcinogenesis, was found to promote efficacy of cytotoxic T-lymphocyte-associated protein 4 (CTLA-4) blockade in melanoma patients [29]. Specifically, presence of $B$. fragilis specific $T$ cell responses were associated with improved efficacy of CTLA-4 blockade [29]. These reports suggest that presence of some bacterial species, their components, and existing or induced immune responses against them might determine the efficacy of some checkpoint inhibitor therapies. These results also highlight, however, that associations alone without information on mechanisms may not be enough to make conclusions about the definitive role of these bacteria in promotion or inhibition of CRC initiation and progression.

\section{Genetic Factors}

Many cases of colorectal cancers occur in people with no family history of the disease. However, individuals with one first-degree relative under 60, or greater than two first-degree relatives of any age, that have had colorectal cancer or adenomatous polyps, are considered to have a significantly higher risk [30,31]. Approximately $20 \%$ of CRC patients have family members that are also affected by this disease. It is estimated that $5-10 \%$ of colorectal cancers are inherited [32]. A single gene, a combination of genes, or a combination of genetic and environmental factors can contribute to familial colorectal cancer. Typically, these families have one or two members with a history of colorectal cancer or pre-cancerous polyps. Mutations in several genes associated with hereditary colorectal cancer have been identified [31,32]. Some of these include mutations in the genes MLH1, MSH2, MSH6, APC, EPCAM, MUTYH, and PMS2. All of these genes are inherited in an autosomal dominant manner except for MUTYH, whose mode of inheritance is recessive [31,32]. The genetic causes of hereditary colorectal cancer syndromes, familial adenomatous polyposis (FAP), Lynch Syndrome, and hereditary nonpolyposis colorectal cancer (HNPCC) have been identified [31-33].

Lynch Syndrome is an autosomal dominant condition that comprises approximately $3-5 \%$ of colorectal cancers. Those with Lynch Syndrome have mutations in mismatch repair genes and hence have an increased propensity to form adenomas and a 20-80\% likelihood of developing certain types of cancer during their lifetime [34]. With this disease, cancer tends to occur at younger ages, and at more proximal locations, rather than sporadically forming. This is in part due to the early formation of polyps and earlier gene mutations in cells [35]. The underlying genetic causes are mutations in DNA causing dysfunction of mismatch repair enzymes. Currently, mutations in four major genes (MLH1, MSH2, MSH6, PMS2), involved in mismatch repair functionality, have been associated with CRC. Each of these genes incurs a different probability of developing colon cancer [35-37].

Familial adenomatous polyposis (FAP) is a common inherited condition that predisposes patients to colorectal cancer. The underlying cause of FAP is a germline mutation in the adenomatous polyposis coli (APC) gene on chromosome 5, which is involved in the adenoma carcinoma sequence [37-39]. This gene codes for the tumor suppressor protein APC, which regulates the growth and division of cells through regulation of the Wnt signaling pathway [39,40]. Mutations in this gene can result in impaired beta-catenin phosphorylation and hence decreased degradation of beta-catenin and result in abnormal cellular survival and proliferation [40]. Mode of inheritance for APC mutations is autosomal dominant; although de novo mutations are also common [31]. This is highlighted by the fact that about one third of FAP patients do not have an affected parent; but can pass the new mutations to their children [38]. Similar to Lynch Syndrome, FAP has extracolonic manifestations and involves the development of polyps in the stomach, fundus, and duodenum in early adolescence [41]. These polyps are at increased risk for malignancy. If patients with FAP are left untreated, polyps may develop into cancer [38]. 
Patient Specific Risk Factors

The risk for colorectal cancer carcinogenesis increases after the age of 40, and progressively increases from there, with a sharp rise after the age of 50 . The incidence rate is 50 times higher in people aged 60-79 compared to those less than 40 years old [32]. Thus, screening is recommended in patients greater than 50 years old, unless other risk factors are present requiring earlier screening [42]. In the United States, $19 \%$ of people may develop adenomatous polyps, which are considered a precursor to colorectal cancer carcinogenesis. Thus, a personal history of adenomatous polyp development increases the risk of colorectal cancer carcinogenesis [32].

Inflammatory bowel disease (IBD) is considered as another risk factor for CRC. IBD consists of both ulcerative colitis and Crohn's disease. 7-14\% of people with IBD have been reported to develop CRC after having the disease for 25 years [30]. Individuals with IBD must undergo more colorectal cancers screenings to detect carcinogenesis early [32]. The increased risk of CRC in IBD could be attributed to the continued inflammation and increased permeability in the colon cell wall.

Diets that contain large amounts of animal fat also have a strong correlation with CRC development [32]. It is hypothesized that such diets promote bacterial flora that degrade bile salts into carcinogenic $N$-nitroso compounds [32,43,44]. Additionally, production of compounds with carcinogenic properties such as heterocyclic amines and polycyclic aromatic hydrocarbons, upon cooking meat with high temperatures, is also linked to CRC. Changes in diet can reduce up to $70 \%$ of an individual's risk for developing colorectal cancer [32]. Other research suggests that differences in the amount of dietary fiber may account for differences in CRC incidences [32,45]

Colorectal cancers have been linked to the amount of physical activity and their overall body mass index (BMI) [32,46]. Frequency and intensity of physical exercise is inversely related to the incidence of colorectal cancer [32]. Smoking also causes harm to the colon and rectum, in addition to the lungs. Twelve percent of colorectal cancer deaths are linked to the carcinogenic effects of tobacco, which increase neoplasm growth in the colon and rectum. Long-term cigarette smoking causes more adenomatous polyp development and is associated with a younger average age of colorectal cancer carcinogenesis and larger polyps [32].

Excessive alcohol consumption is also associated with a younger age of onset of colorectal cancer carcinogenesis, because reactive metabolites of alcohol, like acetaldehyde, are carcinogenic [32]. Excess alcohol can increase tissue permeability and diffusion of carcinogenic molecules into the colonic and rectal tissues. Patients, who drink excess alcohol, are also at risk for malnutrition, thus affecting their diet. The effects of alcohol are also due to free radical oxygen species generation, lipid peroxidation, and prostaglandins production. This is theorized to be due to the induction of cytochrome P-450 2E1 by chronic alcohol use [47]. 
Table 1. Summary of bacterial associations with colorectal cancer (CRC) or promotion of CRC.

\begin{tabular}{|c|c|c|c|}
\hline \multicolumn{4}{|c|}{ Bacterial Associations with CRC } \\
\hline Strain & Model/Samples & Key Findings/Associations & Possible Mechanism(s) \\
\hline Bacteroides fragilis & $\begin{array}{l}\text { Patient samples: } \\
\text { Tissue [9], Stool [10] } \\
\text { Murine model of microbe-induced colon } \\
\text { tumorigenesis [12] }\end{array}$ & $\begin{array}{l}\text { Increased abundance of ETBF in early-stage lesions [9] and stool samples [10] } \\
\text { Bacteroides fragilis toxin (BFT) mediated increase in IL-17 dependent NF-kB activation, } \\
\text { chemokines production and myeloid cell accumulation [12] }\end{array}$ & $\begin{array}{l}\text { BFT mediated tumorigenesis of colonic epithelial cells through } \\
\text { mechanisms dependent on STAT3 activation, and IL-17 signaling } \\
\text { mediated NF-KB activation, production of C-X-C chemokines, and } \\
\text { recruitment of CXCR2-expressing myeloid cells [12] }\end{array}$ \\
\hline $\begin{array}{l}\text { Streptococcus } \\
\text { bovis/gallolyticus }\end{array}$ & $\begin{array}{l}\text { CRC tissues from patients with or without } \\
\text { bacteremia [17] } \\
\text { In vitro with human colonic epithelial cell line } \\
\text { Caco-2; and rat model of azoxymethane-induced } \\
\text { colon carcinogenesis [15] }\end{array}$ & $\begin{array}{l}\text { Concomitant colorectal tumors present in about } 25 \text { to } 80 \% \text { of patients with S. bovis/gallolyticus } \\
\text { bacteremia [14] } \\
\text { S. gallolytyicus isolated from } 20.5 \% \text { and } 17.3 \% \text { tumorous and non-tumorous tissues, } \\
\text { respectively, from CRC patients with bacteremia compared to } 12.8 \% \text { and } 11.5 \% \text {, respectively, } \\
\text { of CRC patients without bacteremia [17] } \\
\text { Increased expression of IL-1, IL-8, and COX-2 in tissues from S. gallolyticus- positive CRC } \\
\text { patients compared to the bacteria negative and control samples }[17] \\
\text { S. bovis wall extracted antigens (WEA) increased release of CXC chemokines and PGE } \text { PGd }_{2} \text { and } \\
\text { increased aberrant crypt formation in vivo. In vitro, WEA increased IL-8 and PGE } \text { release as }_{2} \\
\text { well as increased COX-2 expression and MAPK activation in Caco-2 cells [15] }\end{array}$ & $\begin{array}{l}\text { Increased MAPK activation, bacterial dysbiosis, and overall } \\
\text { increased inflammatory responses [14] } \\
\text { S. bovis WEA promoted formation of pre-neoplastic lesions through } \\
\text { mechanisms dependent on increased release of IL-8 and PGE } 2 \text {, } \\
\text { increased expression of COX-2, and increased activation of MAPK } \\
\text { signals [15] }\end{array}$ \\
\hline Fusobacterium nucleatum & $\begin{array}{l}\text { Stool samples from patients and healthy } \\
\text { controls [16] } \\
\text { In vitro cell line (HCT116), xenograft mouse } \\
\text { model, and human colon specimens [18] } \\
\text { Human NK cells, tumor-infiltrating lymphocytes } \\
\text { (TILs), various human cancer cell lines, and colon } \\
\text { carcinoma tissues [48] }\end{array}$ & $\begin{array}{l}\text { Higher levels of } F \text {. nucleatum detected in patients with adenoma and CRC compared to } \\
\text { healthy controls [16] } \\
\text { Increased FadA (virulence and attachment factor of } F \text {. nucleatum) gene expression detected in } \\
\text { colon specimens of patients with precancerous adenomas or CRC. FadA increased CRC cell } \\
\text { proliferation. [18] } \\
\text { Decreased NK cell killing of tumor cells and decreased activity of TILs upon Fap2 (virulence } \\
\text { factor of } F \text {. nucleatum) binding to TIGIT [48] }\end{array}$ & $\begin{array}{l}\text { FadA promoted the E-cadherin/beta-catenin-mediated proliferation } \\
\text { of CRC cells in vitro and E-cadherin-mediated growth of CRC and } \\
\text { expression of pro-inflammatory cytokines in vivo [18] } \\
\text { Immune evasion mediated by inhibition of NK and T-cell anti-tumor } \\
\text { activity upon Fap } 2 \text { binding to the inhibitory receptor TIGIT [48] }\end{array}$ \\
\hline Enterococcus faecalis & $\begin{array}{l}\text { Retroscopic study of patients with Enterococcus } \\
\text { faecalis infective endocarditis [49] }\end{array}$ & $\begin{array}{l}50.8 \% \text { of patients with unknown source of } E \text { faecalis infective endocarditis were diagnosed } \\
\text { with colorectal neoplasia upon colonoscopy [49] }\end{array}$ & \\
\hline Escherichia coli & $\begin{array}{l}\text { In vitro infection of murine enterocytes and colon } \\
\text { carcinoma cell lines with } E \text {. coli }[50] \\
\text { Human intestinal organoids exposed to } \\
\text { polyketide-peptide genotoxin (Colibactin) } \\
\text { expressing E. coli iver a period of } 5 \text { months [51] } \\
\text { Human monocytic THP-1 cell line differentiated } \\
\text { into macrophages and infected with colon } \\
\text { cancer-associated E. coli strain [52] }\end{array}$ & $\begin{array}{l}\text { Infection of cells with polyketide-peptide genotoxin (Colibactin) expressing E. coli led to a } \\
\text { significant increase in frequency of gene mutation and anchorage-independent colony } \\
\text { formation [50] } \\
\text { Exposure of intestinal organoids to colibactin-producing E. coli led to mutational signature } \\
\text { which is similar to mutational structure found in two independent CRC cohorts [51] } \\
\text { Survival of cancer-associated E. coli intracellularly in macrophages led to persistent increase } \\
\text { in COX-2 expression [52] }\end{array}$ & $\begin{array}{l}\text { Polyketide-peptide genotoxin-induced DNA double stranded breaks, } \\
\text { incomplete DNA repair, and induced aneuploidy and } \\
\text { tetraploidy [50] } \\
\text { Colibactin dependent mutations likely through alkylation of DNA on } \\
\text { adenine residues and subsequent double stranded DNA breaks [51] } \\
\text { Infection by cancer-associated E coli. Increased COX-2 expression by } \\
\text { macrophages in a p38 MAPK dependent manner [52] }\end{array}$ \\
\hline
\end{tabular}

MAPK: Mitogen-activated protein kinase, COX-2: Cyclooxygenase-2. 
Table 2. Summary of bacterial associations with protection from CRC.

\begin{tabular}{|c|c|c|c|}
\hline \multicolumn{4}{|c|}{ Bacterial Associations with Protection from CRC } \\
\hline Strain & Model/Samples & Key Findings/Associations & Possible Mechanism(s) \\
\hline Bifidobacterium longum & $\begin{array}{l}\text { Feces from healthy persons taking or not taking } B \text {. } \\
\text { longum and fructo-oligosaccharides (FOS); Human } \\
\text { colon cancer celll lines [22] } \\
\text { B. longum administration in colitis-induced } \\
\text { murine model of CRC [23] } \\
\text { Rat model of } \\
\text { 2-Amino-3-methylimidazo[4,5-f]quinolone (IQ) } \\
\text { induced colon cancer [24] }\end{array}$ & $\begin{array}{l}\text { Increased amounts of short-chain fatty acids (SCFAs) and decreased Bacteroides fragilis } \\
\text { enterotoxin in feces of individuals taking B. longum and FOS. In vitro, SCFAs, such as butyric } \\
\text { acid, isobutyric acid, and acetic acid, had growth inhibitory activity against colon cancer cell } \\
\text { lines [22] } \\
\text { B. longum administration increased expression of tumor suppressor micro-RNAs (miRs) } \\
\text { miR-145 and miR-155, decreased expression of miR-146a (regulator of interleukins } 1 \beta \text { and } 6 \text { ), } \\
\text { decreased nuclear factor kappa-light-chain-enhancer of activated B cell (NF-KB) activation } \\
\text { and resulted in decreased aberrant crypt foci numbers [23] } \\
\text { Dietary supplementation with B. longum led to 100\% inhibition of IQ-induced incidence of } \\
\text { CRC [24] }\end{array}$ & $\begin{array}{l}\text { Ingesting B. longum with FOS leads to decreased B. fragilis enterotoxin, } \\
\text { increased production of SCFAs, and subsequent inhibition of colorectal } \\
\text { carcinogenesis and cancer cell growth [22] } \\
\text { Decreased expression of oncogenic miRNAs and increased expression of } \\
\text { tumor suppressor miRNAs [23] }\end{array}$ \\
\hline Lactobacillus & $\begin{array}{l}\text { Rat model of 1,2-dimethylhydrazine } \\
\text { (DMH)-induced precancerous growths in } \\
\text { colon [53] } \\
\text { Murine model of azoxymethane (AOM)-induced } \\
\text { colon cancer [54] } \\
\text { Rat model of 1,2-dimethylhydrazine } \\
\text { (DMH)-induced CRC [5] } \\
\text { Rat model of 1,2-dimethyl hydrazine } \\
\text { (DMH)-induced CRC [56] }\end{array}$ & $\begin{array}{l}\text { Lactobacillus acidophilus administration decreased aberrant crypts formation in colon [53] } \\
\text { Lactobacillus acidophilus decreased incidence of colonic lesions by about } 57 \% \text { (compared to } \\
27 \% \text { by Bifidobacterium bifidum) [54] } \\
\text { Lactobacillus salivarius Ren treatment led to } 40 \% \text { decrease in aberrant crypt foci formation [55] } \\
\text { Lactobacillus salivarius Ren treatment led to significant decrease in cancer incidence compared } \\
\text { to controls (from } 87.5 \% \text { to } 25 \% \text { ). Administration of Lactobacillus salivarius Ren reduced } \\
\text { Ruminococcus sp, Clostridiales, and Bacteroides dorei, and increased Prevotella [56] }\end{array}$ & $\begin{array}{l}\text { Lactobacillus acidophilus administration decreased number of } E \text {. coli in feces, } \\
\text { decreased activities of DMH metabolizing enzymes } \beta \text {-glucosidase and } \\
\beta \text {-glucuronidase, and decreased plasma triglyceride concentration [53] } \\
\text { Lactobacillus acidophilus administration significantly increased number of } \\
\text { CD4 } 4^{+} \text {and CD8 } 8^{+} \text {T-cells [54] } \\
\text { Lactobacillus salivarius Ren treatment increased SCFA levels and decreased } \\
\text { azoreductase activity [55] }\end{array}$ \\
\hline Bacteroides fragilis & $\begin{array}{l}\text { Murine model of azoxymethane (AOM)/dextran } \\
\text { sulfate sodium (DSS)-induced colitis-associated } \\
\text { CRC [13] } \\
\text { Human CRC cell lines in vitro [57] }\end{array}$ & $\begin{array}{l}\text { B. fragilis colonization decreased DSS-induced inflammation and colitis, and decreased size } \\
\text { and numbers of AOM/DSS-induced colitis-associated CRC tumors [13] } \\
\text { B. fragilis Polysaccharide A (PSA), in TLR2 dependent manner, inhibited proliferation of CRC } \\
\text { cells by suppressing cell cycle progression (downregulation of CCND1 and CDK2, } \\
\text { upregulation of CDKN1B). PSA suppressed EMT and decreased migration and invasion of } \\
\text { CRC cells in vitro [57] }\end{array}$ & $\begin{array}{l}\text { Protection against CRC was dependent on B. fragilis polysaccharide A } \\
\text { production and toll-like receptor } 2 \text { (TLR2) signaling and associated with } \\
\text { inhibition of C-C motif chemokine receptor5 (CCR5) in colon [13] } \\
\text { Inhibition of cell cycle progression and inhibition of EMT and cancer cell } \\
\text { migration and invasion in TLR2 dependent manner [57] }\end{array}$ \\
\hline Clostridium & $\begin{array}{l}\text { Murine model of 1,2-dimethylhydrazine } \\
\text { dihydrochloride (DMH)-induced CRC and human } \\
\text { colon cancer cell lines [58] } \\
\text { Murine model of high-fat diet (HFD)-induced } \\
\text { intestinal tumor [59] }\end{array}$ & $\begin{array}{l}\text { Clostridium butyricum decreased DMH-induced colon cancer incidence from } 90 \% \text { to } 30 \% \text { [58] } \\
\text { Oral administration of Clostridium butyricum led to significant decrease in numbers of } \\
\text { HFD-induced intestinal tumors [59] }\end{array}$ & $\begin{array}{l}\text { Clostridium butyricum inhibited proliferation of colorectal cancer cells, } \\
\text { increased cell-cycle arrest and apoptosis of colon cancer cells, and } \\
\text { modulated T-cells [58] } \\
\text { Clostridium butyricum increased SCFAs and G-protein coupled receptor } \\
\text { GPR43, suppressed tumor cell proliferation, increased tumor-cell } \\
\text { apoptosis, and suppressed the Wnt } \beta \text {-catenin signaling pathway [59] }\end{array}$ \\
\hline
\end{tabular}




\subsubsection{Therapeutic Targets in Colon Cancer}

Colon cancer therapy is a rapidly evolving field. Many therapeutic targets have been established while others are still under investigation. Below, we briefly discuss possible targets that might be associated with or affected by probiotics and bacteria.

Cytokines

Inflammatory cytokines in colon cells such as interleukins 6 and 17 (IL-6, IL-17) are involved in human colonic carcinogenesis. They have been shown to be increased in patients with CRC $[60,61]$. They induce the oncogenic STAT3 pathway and activate proliferative, anti-apoptotic, and pro-carcinogenic genes involved in cancer growth $[12,61,62]$. The essence of the inflammatory process related to cytokines is based on human colonic bacteria. For example, enterotoxigenic Bacteroides fragilis (ETBF), which secretes the $B$. fragilis toxin, triggers colitis and induces proinflammatory cytokines such as IL-17 to activate colonic neoplasia [61]. The use of probiotics can provide a stable equilibrium of gut flora by diversifying the microbiota population, which will in turn reduce toxins secreted by overpopulated B. fragilis [60,61].

Interleukin-23 (IL-23) may be involved in autoimmune inflammatory diseases (i.e., colitis, IBD) and is crucial for carcinogenesis. Colonization with Escherichia coli can increase IL-23 release by immune cells and may lead to cancer cell proliferation $[63,64]$. IL-23 has been shown to promote tumor growth, increase angiogenesis, increase matrix metalloproteinase (MMP9; an enzyme for extracellular matrix degradation) production, and curb cytotoxic T-cell recruitments to the tumors [65]. Altered microbial composition can be reversed by using probiotics to reduce genotoxicity and bring balance to gut microbiota, which may lead to reduced risk of CRC development by reducing the production of cytokines that induce tumor-promoting inflammation [66].

Transforming growth factor beta (TGF- $\beta$ ) has an essential role in inhibiting cell proliferation along with controlling immune regulation and microenvironment. It aids in regulating cell growth, death, and motility. Interestingly, both loss of TGF- $\beta$ signaling and overexpression of TGF- $\beta$ have been associated with CRC development and metastasis. Studies suggest that while TGF- $\beta$ may have a tumor suppressor role in early stages of neoplasia development, it tends to promote growth and metastases in the later stages [67-72]. Its role in cancer allows the abnormal cells to continue to prevail and grow. Growing evidence suggests that TGF- $\beta$ is also regulated by the microbiota. Clostridium bacteria has been shown to produce short chain fatty acids (SCFAs) such as acetate, propionate, and butyrate can increase the expression of TGF- $\beta$ by epithelial cells in the colon; however, the mechanism of this relationship is not well studied [71].

Prostaglandin G/H Synthase

Prostaglandin-endoperoxide synthase (PTGS) promotes cell proliferation and has been associated with CRC incidence [73,74]. It also plays a central role in pro-inflammatory responses. Chronic inflammatory reaction in colorectal cancer is due to overexpression of PTGS2 by Streptococcus gallolyticus member bacteria (SGMB), which is believed to disrupt normal gut microbiota [48]. Probiotics may help replenish and introduce a variety of microorganisms to the intestinal flora.

\section{Proto-Oncogene RAF}

RAF genes are essential in the RAS-RAF-MAPK signaling pathway. Overactivation of this signaling network results in cell proliferation, differentiation, and survival [75]. Activating mutations in RAF have been linked to approximately $8-12 \%$ of metastatic CRC cases [75]. Microbial imbalance exhibits loss of commensalism and diversity. This disproportion induces inflammation and promotes overexpression of inflammatory cytokines, which in turn lead to DNA damage [8]. The process of cancer development passes through a cascade of events that involves activation of proto-oncogenes such as c-RAF $[8,75,76]$. Restoring symbiotic gut microbiota by using probiotics may reduce chronic 
inflammation, overexpression of cytokines, and activation of proto-oncogenes by regulating the expression or mutation of the gene. The use of probiotics may restore microbial imbalance by restoring the health promoting bacterial strains.

\section{Vascular Endothelial Growth Factor (VEGF)}

This growth factor (GF) regulates vascular permeability and development [77]. Bacteria have been shown to up-regulate intestinal VEGF expression [78]. VEGF signaling in colorectal cancer cells can promote colorectal cancer migration and invasion [79]. It has been shown that gut microorganisms can trigger mucosal endothelial and mesenchymal cells to promote TLR-dependent angiogenic responses involving VEGF [80]. Probiotic usage may offset changes in gut microbiota composition and decrease the promotion of angiogenic response and proinflammatory factors.

\section{Fibronectin}

High expression of fibronectin (a glycoprotein for cell adhesion) is associated with cellular proliferation and poor prognosis in CRC [81]. This glycoprotein serves as a cell-to-cell adhesion molecule. It promotes fibroblast migration, macrophage function, and binding of pathogens such as bacteria to mammalian cells. In colorectal cancer, fibronectin facilitates cellular proliferation, adhesion, tumor cell migration, epithelial to mesenchymal transition (EMT), metastasis, and induction of immunosuppression [81,82]. Colonization of S. bovis/gallolyticus in colorectal tissues through fibronectin adhesion and collagen-binding can cause serious inflammatory response $[14,83]$. Escalation of the inflammatory response induces proinflammatory and angiogenic cytokines, leading to the development of colorectal cancer. Imbalance of the gut microbiota is promoted by over colonization of a specific commensal bacteria, which may be corrected by supplementing probiotics to restore diversity and abundance of gut flora $[14,82,83]$.

\subsubsection{Current Treatment and Its Limitations}

Treatment options for colorectal cancer depend on staging and localizations. Staging is based on the TNM system: $\mathrm{T}$ is the size and extent of the primary tumor; $\mathrm{N}$ is the extent that the cancer has spread to the lymph nodes; and $\mathrm{M}$ is whether the primary tumor has metastasized [84,85]. The initial treatment of colorectal cancer usually begins with surgical resection of the primary tumor(s) and associated lymph nodes (colectomy and/or lymphadenectomy) and an application of chemotherapy for stages III and IV of the disease [85].

Fluoropyrimidines (thymidylate synthase inhibitors) such as 5-Fluorouracil (5-FU), capecitabine, and floxuridine are used as first line monotherapy. They inhibit thymidylate synthase, resulting in decreased DNA replication and cell growth, and are generally used to treat a variety of cancers [86]. These must be administered with leucovorin to enhance fluorouracil efficacy by increasing its binding to the enzyme and are sometimes given orally with cytotoxic agents (oxaliplatin, a platinum agent or irinotecan, a topoisomerase I inhibitor) to treat colorectal cancer [87]. Primary chemotherapeutic regimens FOLFOXIRI (fluorouracil, leucovorin, oxaliplatin, and irinotecan) and FOLFIRI (infusional fluorouracil, leucovorin, and irinotecan) have significantly improved colorectal cancer treatment. The new chemotherapeutic regimens FOLFOXIRI and FOLFIRI, combined with new drugs such as cetuximab (epidermal growth factor receptor inhibitor), have improved the prognosis of recurrent or metastatic colorectal cancer patients by boosting response rates in clinical trials [85].

Some new drugs have recently been approved for the treatment of colorectal cancer and include epidermal growth factor receptor (EGFR) inhibitors [88]. Recently, aflibercept (a vascular endothelial growth factor B (VEGFB) inhibitor) was also approved for the adjuvant treatment of metastatic colorectal cancer $[88,89]$.

Inhibitor of apoptosis protein (IAP) family is considered a candidate for a new therapeutic target for colorectal cancer. This family of proteins play a crucial role in the regulation of apoptosis [90]. Survivin, a member of IAP family of proteins, is an inhibitor of apoptosis; and it has been shown 
to be elevated in many cancer types including colon [90]. In a study looking at the gene expression of survivin in HT-29 colon cancer cells, it was found that those treated with exopolysaccharides (EPS) from Lactobacillus bacterium had decreased gene expression of survivin, which resulted in increased apoptosis [91]. MicroRNA (miRNA) is also being examined as a potential therapeutic target for the treatment of colorectal cancer. miRNAs are involved in tumor progression, growth, and metastasis [92]. Currently, different miRNAs are being used as biomarkers and for detection and prognosis. Whether this target has therapeutic potential is still being investigated [92,93].

Probiotics have been investigated as a novel therapy for the prevention of colorectal cancer. It has been suggested that probiotic metabolites and their molecular signaling cascades might be utilized as epigenetic therapeutic targets. Further initial evidence has suggested that probiotics might also be used to actively treat colon cancer due to the involvement of leptin and environmental factors affecting colon cancer carcinogenesis. Leptin is a hormone, derived from adipose tissue, that helps to modulate different physiological processes (metabolic rate, reproduction, and immune response). Serum levels of leptin and expression of its receptor (LPR) are often altered in human colon tumors and leptin has been suggested as a risk factor for colon cancer $[94,95]$. Probiotic non-pathogenic bacteria consumption can decrease the expression of LPR, suggesting that probiotics may be the source of a novel therapy for colon cancer to improve survival rates [95].

Microsatellite instability (MSI), which is due to DNA mismatch repair (MMR), is usually not inherited. This occurs in around $15 \%$ of patients that get sporadic CRC [96]. It is also common, up to $70 \%$, in the patients with loss of expression of MLH1 and PMS2 or with MLH1 methylation to have a BRAF V600E (a gene that increases cell growth) mutation [96]. Thus, germline testing is recommended if there is a strong family history of MSI. The MMR enzymes fix the errors that happen during DNA replication. If an individual has MMR deficiency (dMMR), the build-up of the errors during replication causes DNA to become unstable, resulting in MSI (microsatellite instability). MSI screening can identify tissues with a high amount of instability (MSI-H). The latest guidelines also include additional explanation of MMR immunohistochemistry testing for the four genes known to be mutated in Lynch Syndrome (MLH1, MSH2, MSH6, and PMS2) [96]. With regard to the treatments based on dMMR or MSI, different immunotherapy treatment options listed in the National Comprehensive Cancer Network (NCCN) guidelines for advanced or metastatic CRC are nivolumab (Opdivo), pembrolizumab (Keytruda), or a combination of nivolumab and ipilimumab (Yervoy), both in dMMR and MSI-H only. These recommendations are category $2 \mathrm{~B}$ and are intended for patients who are not appropriate candidates for cytotoxic combination regimens. These same immunotherapy options are also listed in the guidelines as second- and third-line recommendations for dMMR/MSI-H patients [85]. MSI-tumors are more common in right sided CRC for an unknown reason. These tumors commonly use checkpoint regulators to remain alive and avoid the immune system; thus, checkpoint inhibitor immunotherapies such as pembrolizumab (a programmed death 1 inhibitor) have been shown to be efficacious [7].

Larotrectinib (Vitrakvi; tropomyosin kinase receptor inhibitor) is now a second-line treatment option for patients with metastatic CRC that is neurotrophic receptor tyrosine kinase (NTRK) gene fusion positive [97-99]. The gene fusion occurs when the NTRK $1 / 2 / 3$ genes fuse with other genes, resulting in altered TRK protein (TRKA, TRKB, and TRKC) that activate signaling pathways for the proliferation of certain types of cancer. In the phase I trial, patients were given $50 \mathrm{mg}$ of larotrectinib orally and were monitored for the primary endpoint of toxicities and safety. As a result, it was found that the drug was effective (in antitumor activity) and safe (minimal toxicities) [97]. The most common moderate toxicity that occurred was anemia, occurring in $6 \%$ of the 70 patients in the trial [97]. In further trials, the drug showed an overall response rate of $75 \%$ (complete response in $22 \%$ and partial response in 53\%) [98]. In November 2018, the Federal Drug Administration (FDA) accelerated the approval of larotrectinib for the treatment of adult and pediatric patients with solid tumors, positive for a NTRK gene fusion without a resistance mutation [99]. The resistance mutation is found in the TRKA kinase domain; resistances are obtained by point mutations and include G623R, G696A, and F617L $[97,98]$. It is recommended in higher stages: tumors that are metastatic or where surgical 
resection is likely to result in severe morbidity, and when no satisfactory alternative treatments are available or that have progressed following treatment [99].

There are a variety of combination therapies that have been added to the guidelines as second line options. Some include dabrafenib (Tafinlar, BRAF inhibitor) plus trametinib (Mekinist, MEK inhibitor) plus cetuximab or panitumumab (mAB inhibitors of EGFR), another option is encorafenib (Braftovi; BRAF inhibitor) plus binimetinib (Mektovi; MEK inhibitor) plus cetuximab or panitumumab (EGFR inhibitor monoclonal antibody) [100-102]. These studies show that new therapies are arising and that patient factors (genetics, mutations, and resistance mechanisms) should be considered for determination of optimal treatment options.

\subsection{Probiotics}

According to the Food and Agriculture Organization of the United Nations (FAO) and the World Health Organization (WHO), probiotics are "live microorganisms, conferring health benefits on the host when administered in adequate amounts" [103]. So, probiotics are live bacteria that can be added to any human diet as supplements that can potentially confer health benefits. Higher order vertebrates have been in a symbiotic relationship with microorganisms for millions of years on Earth, effectively co-evolving together.

Humans are no exception to this relationship as it is estimated that 100 trillion different bacteria divided into 1000 different species inhabit the human gastrointestinal tract. The human gut microbiome is believed to have around three million functional genes compared to 23,000 genes in human beings; this far larger genome of the microbiome has correspondingly greater functional capabilities in modulating human physiology [104]. The human microbiome is now considered a fully functional additional organ that is highly adaptable, flexible, and organized with key functions for human health $[103,104]$.

Humans acquire unique microbiota concentrations during natural processes at the inception of life, beginning with the passage through the birth canal and continuing via breastfeeding [105]. Different modes of child delivery have been shown to lead to different compositions of human microbiota: vaginally delivered babies have higher concentrations of Bifidobacterium than babies delivered via C-section [105] Infants who are breastfed also have higher concentrations of Bifidobacterium compared to those who are formula-fed; formula-fed babies have a higher concentration of Enterococci. There have been some associations with different disease susceptibility based on this early difference in microbial colonization. Beyond the effects of birthing method(s) and childhood diet, research has shown different microbiota arise from different kinds of diets in more mature humans. For example, rural African children have higher Bacteroides, lower Firmicutes, and display lower incidence of irritable bowel disease (IBD) when compared to European children with typical Western diets [106].

\subsubsection{History and Rationale behind the Use of Probiotics in Cancer}

Genetics and environmental factors are the two main contributing factors to CRC. Other risks include IBD and the microbial composition of the intestines. Microbiota compositions have been shown to affect the following processes: epithelial cell proliferation and differentiation, production of bioactive food products and nutrients, prevention of overgrowth of pathogenic organisms, and stimulation of immunity (refer to Table 3 for a summary of the roles played by healthy human microbiota). To a large extent, the exact mechanisms by which the composition of microbiota are linked to CRC are still unknown. At present, studies have discovered evidence that normal microbiota are composed of both beneficial and pathogenic bacteria. If the pathogenic bacteria grow too rapidly, an inflammatory process can be triggered, resulting in the production of carcinogenic compounds. It is vital to recognize the role that healthy flora plays in protecting us against detrimental health conditions. Bacteria in our gut compete with potential invaders for space and nutrients as well as produce bacteriocins, which act as antibacterials to eliminate harmful bacteria from our intestines [102,104,105,107-110]. Thus, it is important that the balance of the normal gut floral remains at homeostasis. 
Table 3. Mechanisms the probiotics can have on the body.

\begin{tabular}{ll}
\hline $\begin{array}{l}\text { Nonspecific Physiological } \\
\text { Mechanisms }\end{array}$ & $\begin{array}{l}\text { Immunological } \\
\text { Mechanisms }\end{array}$ \\
\hline Initiate antiproliferative and apoptotic signaling in colorectal cancer cells & Modulate immune functions in gut mucosa \\
\hline Bolster the intestinal mucosal barrier function & Induce natural killer cells \\
\hline Inhibition of the enzymatic activity of pathogenic bacteria & Helps in immune maturation and maintenance \\
\hline Inhibition of carcinogenic agents & $\begin{array}{l}\text { Diversified gut flora positively modulates T-regulatory } \\
\text { cells against tumor cells }\end{array}$ \\
\hline
\end{tabular}

Dysbiosis, microbial imbalance in gut or malabsorption in our body, can be caused by environmental factors (such as diet, infection, and antibiotics). Tackling dysbiosis and the effects of harmful bacteria with replacement through the use of probiotics results in protection against CRC or therapeutic response to different drugs in CRC. According to a murine study on the influence of gut microbiota dysbiosis to the efficacy of 5- Fluorouracil (5-FU), initial gut microbiota community composition is the key factor driving host response to the antitumor drug of 5-FU, which helped in exploring the potential probiotics may possess to enhance the efficacy of antitumor drugs $[8,111]$. Probiotics is a term used to describe healthy bacteria that have a beneficial effect on the body; lactic acid producing bacteria (LABs) such as Lactobacillus and Bifidobacterium species are the most common types that are found in the gut [109]. In the study by Yuan et al., probiotics with these species were used to show the results in increased response to the drug [111]. Probiotics maintain gut integrity, regulate bowel movement, improve lactose intolerance, thereby improving immunity and helping prevent harmful bacterial overgrowth and yeast infection. Probiotics are different from prebiotics. Prebiotics are carbohydrates that act as fuel for probiotics and are non-digestible in the human body. They support the growth or activity of the probiotics $[112,113]$. Both probiotics and prebiotics (used together in synbiotics) can aid in the prevention of dysbiosis.

It is important to understand the key players involved in maintaining the gut microbiota balance because it can potentially be prophylactic against CRC. Several studies have documented differences in microbiota composition between healthy individuals and patients with CRC [108,112]. One study found that the stool of CRC patients contained more Bacteroidetes/Prevotella when compared to healthy patients [114]. The core human colonic commensal microflora is composed primarily of Firmicutes, Bacteroidetes, Proteobacteria, and Actinobacteria with concentrations a million-fold higher than in the small intestine. Even though there are broad similarities in the proportion of general categories of commensal microbes, there are significant differences between apparently healthy individuals at lower taxonomic levels. Abnormalities in the host microbiome composition and/or function are associated with the etiology of cancer pathogenesis [108,114].

Another study was conducted to find out the differences between the normal and colorectal cancer mucosa bacterial composition. This study by Gao et al. aimed to find out how probiotics affect the microbiota in colorectal cancer patients. The results of the study showed that patients with colorectal cancer have different bacterial composition compared to mucosa of the normal healthy control group [115]. The study also found that colorectal cancer mucosa showed significantly increased concentrations of Fusobacterium, Selenomonas, and Peptostreptococcus after probiotic use. Aside from this finding, a group of patients in the study who had colorectal cancer were given probiotics for almost a month and biopsies were collected just before they underwent surgery. The probiotics included live Bifidobacterium longum, Lactobacillus acidophilus, and Enterococcus faecalis. The biopsies all contained increased concentrations of butyrate-producing bacteria such as Faecalibacterium and Clostridiales, and decreased concentrations of Fusobacterium and Peptostreptococcus. Peptostreptococcus and Fusobacterium play a role in colorectal cancer pathogenesis and can therefore be used as biomarkers to detect the disease in early stages. Additionally, this study, as well as other literature, highlight how there is a difference in bacterial composition between healthy and CRC patients, and how supplementing the diet of CRC patients with probiotics can change their microbiota for clinical benefits $[115,116]$. 
Similarly, another paper highlighted the fact that CRC patients have an abundance of Fusobacterium [117]. This can be exploited to detect CRC polyps earlier than current diagnostic methods. With regard to the mechanisms through which Fusobacterium promotes carcinogenesis, it has been suggested that, due to its interaction with E-cadherin, it enhances the malignant potential of $\mathrm{CRC}$ by increasing inflammation and antagonizing the immune function of $\mathrm{T}$ cells. Another proposed mechanism is that Fusobacteria may promote colorectal cancer by activating Wnt/ $\beta$-catenin signaling and damaging DNA ROS production and activation of oncogenes [117]. Others have reported enrichment of enterotoxigenic Bacteroides fragilis and Enterococcus faecalis in feces of patients with colorectal cancer compared to healthy controls $[83,118]$. E. coli has also been shown to promote the onset of CRC by expressing a polyketide synthase gene that is involved in inflammation, cell proliferation, and epithelial cell injury via a direct invasion of the epithelial cell layer [119]. The polyketide synthase gene also enhances the activity of cyclooxygenase 2 (COX-2), which is linked to CRC by several additional studies $[116,119]$. There are many toxins produced as a result of microbiota dysbiosis. One of those toxins is the B. fragilis toxin (BFT). BFT interacts with Wnt/B-catenin and nuclear factor kappa B at the molecular level; all three mediate inflammation and cell proliferation, thus contributing to carcinogenesis [8]. Toxins can also have directly damaging effects on DNA [8]. Another example is polyketide peptide toxin, which creates gene instability [50]. Additional mechanism involved in carcinogenesis when dysbiosis occurs is the fact that pathogenic bacteria contain enzymes such as beta-glucuronidase and azoreductase. These enzymes are capable of converting byproduct molecules from a person's diet into carcinogenic substances [55]. Probiotics have been shown to decrease the secretion of these enzymes and limit this conversion of byproduct molecules into carcinogenic substances, thus potentially reducing rates of CRC occurrence $[8,55,115,119]$. Figure 1 contains a summary of the actions that probiotics have, along with possible therapeutic targets.

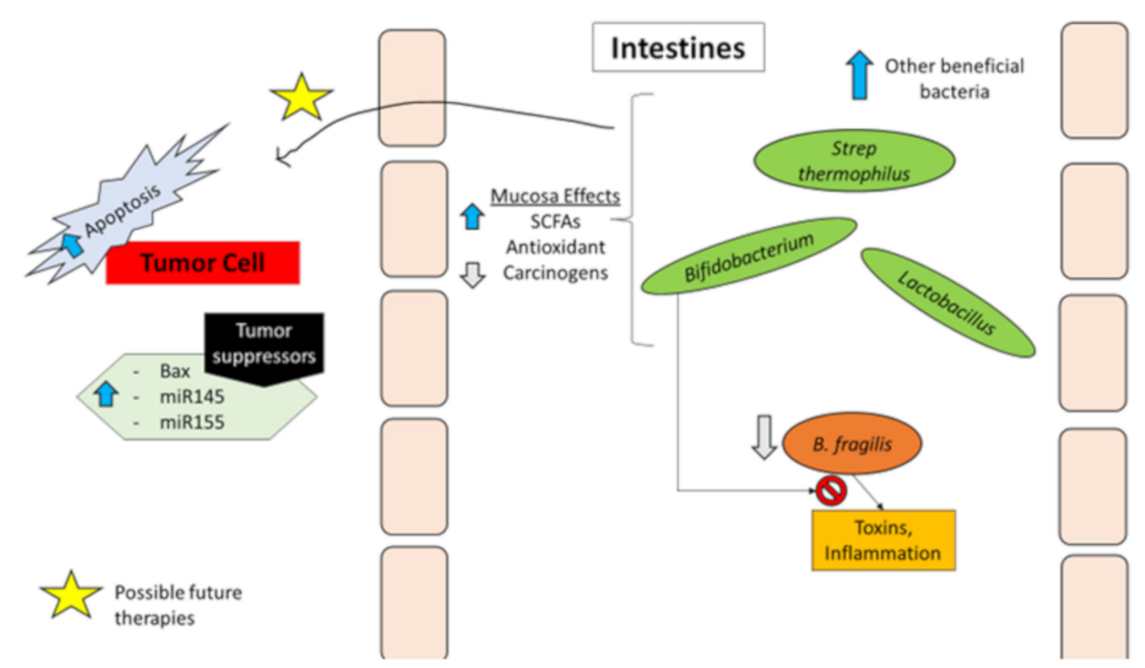

Figure 1. Mechanisms of probiotics. Probiotics increase other beneficial bacteria, while decreasing pathogenic bacteria and their harmful mechanisms. They have also been shown to increase short chain fatty acids (SCFAs) and antioxidants, while also decreasing carcinogens in the intestines. Possible actions that probiotics have are to increase tumor cell apoptosis and increase in tumor suppressor genes; these may be possible areas to research further into for colorectal cancer (CRC) prevention and adjuvant therapies.

\subsubsection{Types or Strains Used}

Studies have revealed that the colorectal cancer microbiome differs from that of nearby normal tissue with diminished diversity and distorted community structure, lower relative abundance of potentially protective short chain fatty acid-producing bacteria, and increased abundance of taxa with potentially carcinogenic inducing phenotypes [114]. However, it is currently unclear whether 
this change in microbiome is a risk factor for colorectal cancer development or if it contributes to downstream pathogenesis signaling processes.

Lactic acid bacteria (LAB) are a highly common type of probiotic inhabiting human intestines, which have many useful functions. Amongst those functions is the antitumor property possessed by the exopolysaccharides (EPS) that are produced by lactic acid bacteria. EPS are polysaccharides that are located outside of the cell wall. A recent experiment examining the antitumor property of EPS involved obtaining human colon cancer cells HT-29 and inoculating with EPS obtained from different strains of Lactobacillus [91]. The study found morphological changes in the chromatin of cells that were inoculated with EPS and an anti-proliferation effect on H-29 cells in vitro [91]. It was also found that the inhibition is dependent upon dose with an optimal concentration of $500 \mathrm{mcg} / \mathrm{mL}$ of EPS being essential to maximize the anti-proliferation effect. The effect of EPS on cell cycle phase distribution and apoptosis was also examined. A higher percentage of cells treated with EPS were found to be in G0/G1 compared to S/G2. In addition to its effect on cell cycle phase distribution, EPS inoculation induced apoptosis in H-29 cells [91].

Lactobacillus and Bifidobacterium are among the most commonly studied bacteria that have promising properties for use in the treatment of colon cancer. These properties include anti-apoptotic, anti-proliferative, and antioxidant effects on cancer cells. It has been shown that lactic acid bacteria enhance the action of pro-apoptotic proteins involved in the cell cycle such as Bax, and they downregulate anti-apoptotic proteins such as Bcl-2 [120]. It is not currently understood which component or product of bacteria exerts these pro-apoptotic effects on cancer cells, but it has been hypothesized that it is due to short chain fatty acids (SCFA) produced by the bacteria, particularly butyric acid. SCFA are the products of bacterial fermentation of non-digestible carbohydrates [27]. Normal cells typically utilize butyric acid as a carbon source for energy production. It has anti-apoptotic effects on noncancerous cells and has been shown to prevent the proliferation of cancerous cells [121,122]. At the molecular level, butyric acid was noted to act as a histone deacetylase inhibitor in cancer cells leading to the acetylation of the pro-apoptotic genes, hence increasing their expression [122,123]. Butyric acid also decreases the expression of the genes for cyclin D1 (a regulator of cell progression in G1 and S phase of the cell cycle), which have been hypothesized as playing an essential role in CRC pathogenesis [124,125]. Histone deacetylase inhibitors (HDAC inhibitors) cause DNA strain and possible breakage in both normal (non-cancerous cells) and cancerous cells. However, normal cells can recover from this destruction and will repair themselves while the cancerous cells cannot [126]. Gut microbiota can contribute to HDAC inhibition through production of butyrate, valeric and hexanoic acid, which are thought to contribute to the HDAC inhibitory effects [127]. In addition, Lactobacillus acidophilus has been found to increase the pro-apoptotic effects of the typical anticancer treatment, 5-Fluorouracil, and it increases the expression of caspase-3, resulting in cell death [107]. Probiotics also stimulate the production of mucins in the intestines, which acts as a protective barrier against pathogenic bacteria $[107,128]$. SCFAs are also a source of energy that aids in the proliferation of healthy cells [122]. Due to these qualities, the adequate production of SCFA is an important indicator of healthy microbiota. Appropriate diet consumption plays an important role in determining the presence of symbiotic microbiota that carry out many important functions including the fermentation of food products and the subsequent production of beneficial SCFAs [107,122].

Another study was conducted to investigate the effect of probiotics on the production of SCFA and the composition of the intestinal flora (such as putrefactive bacteria) and Bacteroides fragilis enterotoxin (ETBF) [24]. SCFAs such as butyric acid exerts growth inhibitory and pro-apoptotic effects on cancer cells $[24,107,129]$. In the study by Ohara et al., the researchers attempted to directly examine the role of probiotics and prebiotics in colon cancer prevention by directly measuring the amount of SFCA, putrefactive bacteria, and ETBF in human fecal samples [24]. After extraction of these samples, human colon cancer cell lines were subjected to those SCFAs to test for anti-proliferative properties. For human study, subjects were divided into two groups: (1) was given yogurt containing only Bifidobacterium longum (a probiotic), and (2) was given both Bifidobacterium longum as well as fructo-oligosaccharides 
(a prebiotic). The results of the study showed that ETBF and fecal putrefactive products were significantly reduced after five weeks of consuming probiotics. Additionally, SCFA production was increased (especially butyric and isobutyric acid) in both groups with the introduction of probiotics and prebiotics into the subject's diets [24].

Another proposed mechanism is the prevention of conversion of procarcinogens to carcinogens by the enzymatic detoxification and biotransformation carried out by strains of Lactobacillus and Bifidobacterium [130]. For example, L. rhamnosus has been shown to bind to $\mathrm{N}$-methyl- $\mathrm{N}^{\prime}$-nitro- $\mathrm{N}$-nitrosoguanidine (a carcinogen and mutagen), leading to biotransformation and detoxification. In vivo in rats, oral administration of L. rhamnosus led to protection against $N$-methyl- $N^{\prime}$-nitro- $N$-nitrosoguanidine induced damages [131]. In addition, certain strains like L. acidophilus have been shown to decrease the activity of the enzymes beta-glucuronidase, azoreductase, and nitroreductase [131]. These enzymes have been shown to be involved in tumor formation; they convert procarcinogens into carcinogens. For instance, they act on polycyclic aromatic hydrocarbons, heterocyclic aromatic amines, and primary bile acids to convert them into carcinogens [131].

Another proposed mechanism is immunomodulation through the production of anti-inflammatory cytokines [132,133]. Probiotics have been shown to increase the production of anti-inflammatory cytokines, increase phagocytosis by macrophages, and increase tumor cell apoptosis. Probiotics have been found to have these effects to some degree, resulting in lower tumor progression [132,133]. Probiotics are also involved in maintaining an adequate intestinal $\mathrm{pH}$ level. Elevated $\mathrm{pH}$ and decreased SCFAs have been found in the faeces of patients with CRC, suggesting an inverse relation between SCFAs and $\mathrm{pH}$ [134].

As above-mentioned, it is not only the probiotic itself that is useful, but the metabolites that they produce. Nisin is a bacteriocin produced by Lactococcus lantis, which has been shown to have anti-metastatic effects on cancer cells. A study was conducted to evaluate the effect of nisin on the expression of genes involved in metastasis such as CEA, CEAM6, and MMP2F [135]. These genes are linked to unregulated growth, immune evasion, metastasis, and resistances. This study revealed that nisin reduced the expression of all of these genes as well as decreased the protein expression of carcinoembryonic antigen (CEA) [135].

\subsubsection{Current Products on Market}

Commercial probiotics use different strains of bacteria such as Lactobacillus rhamnosus, Bifidobacterium longum, and Bifidobacterium lactis [136]. Kefir, a fermented milk probiotic, can contain Streptococcus, Lactococcus, Lactobacillus, Leuconostoc, Bifidobacterium bifidum, and Acetobacter species and also some yeast species (Saccharomyces, Kluyveromyces, and Candida) [137]. It has been proven to have powerful anticancer properties. At the molecular level, Kefir contains bioactive peptides that are involved in the activation of macrophages and enhancing phagocytosis. Kefir also increases the production of anti-inflammatory cytokines such as IL-4 and IL-10, and also leads to an increased IgA secretion, improving mucosal immunity and decreasing inflammation $[137,138]$. In addition, it has been shown to decrease the expression of anti-apoptotic gene Bcl-2 while increasing the expression of the pro-apoptotic gene Bax in gastric cancer cells $[137,138]$. Kefir also reduces DNA damage through its anti-oxidative properties, which include increasing the level of glutathione peroxidase and decreasing the level of malondialdehyde [138]. A study has shown that the supernatant of kefir contains lactic and acetic acid with antioxidant properties reducing DNA damage and causing G1 cell cycle arrest in colorectal cancer cells $[137,138]$.

VSL\#3 (Value of Statistical Life) packets is another probiotic formulation. It contains between 112.5 and 900 billion live colony forming units (CFU); it utilizes a combination of diverse strains of bacteria such as Streptococcus thermophilus, different types of Bifidobacterial such as longum, infantis, and breve [139]. VSL\#3 also includes different types of Lactobacillus (acidophilus, plantarum, paracasei, delbrueckii). In a preclinical study, it was shown that VSL\#3 administration led to decreased inflammation 
and delayed onset of colonic dysplasia and cancer [140]. However, in a study of azoxymethane induced colitis-associated CRC in mice by Arthur et al., it was determined that giving VSL\#3 did not protect against inflammation and CRC tumorigenesis [141].

Culturelle capsules contain Lactobacillus rhamnosus with 10 billion CFUs per capsule, but also contain $200 \mathrm{mg}$ inulin (a prebiotic) [142]. This is an example of synbiotics (prebiotics and probiotics together). The microorganism in this product (Lactobacillus rhamnosus) has shown in one study to alter fecal microorganisms and prevent increase of IL-2 in patients with colorectal cancer [143]. The possible outcomes of the decrease in IL-2 were not noted in the article. However, low levels may not have a beneficial effect on patients with preexisting CRC, since IL-2 helps to activate the immune system $[143,144]$. The study was most likely looking at the prevention measures that the probiotic could result in. Culturelle is also one of the top over the counter probiotics on the market.

Activia yogurt contains Bifidobacterium animalis subsp lactis DN-173 010; with 100 million CFUs per gram $[136,142]$. This product has been studied in patients with colorectal cancer. It was found to decrease inflammation by decreasing nitric oxide and cytokine production [143]. Thus, it may be beneficial in the prevention and/or treatment of CRC.

DanActive Cultured Milk is a probiotic product that contains S. thermophilus and L. bulgaricus in addition to L. casei DN-114 001. Each serving contains one billion CFUs per 3.1-ounce bottle [142]. This has not specifically been studied in colorectal cancer, but in a study on breast cancer in mice, it showed potential for anticancer actions [143].

\subsubsection{Clinical Trials}

Current clinical trials have researched the benefits of probiotics. Studies, which were obtained online using PubMed and ClinicalTrials.gov, were mainly conducted on adults (greater than 18 years old) who had CRC. Many trials have studied non-metastatic cancer. Several have also attempted to reduce any bias in the study by excluding patients taking antibiotics or other prebiotics/probiotics/synbiotics in a certain timeframe. This was done to limit the impact these items would have on the gut microbiome. Some of the trials examined probiotic use and its effect on inflammatory factors (TRG1-2, cytokines) and mucosal proliferation. Results show these may be better markers to demonstrate benefits in CRC patients. Even though several studies may indicate clinical significance in the use of probiotics in the supplementation to CEC treatment as well as preventative measures, most state that further studies with larger cohorts are necessary to fully prove this theory. Clinical trials examined for this article are shown in Tables 4 and 5. These trials show that probiotics aid in normal gut flora health, and they have effects on inflammatory factors and a possible role in colorectal cancer treatment. Many of these studies have not published their results separately. 
Table 4. Clinical trials on probiotics in cancer.

\begin{tabular}{|c|c|c|c|c|c|c|c|c|}
\hline Study Title & NCT\# & Status * & Intervention & Study & Inclusion/Exclusion Criteria & Outcomes & Results & Published * \\
\hline $\begin{array}{l}\text { An Evaluation of Probiotic in the } \\
\text { Clinical Course of Patients with } \\
\text { Colorectal Cancer [145] }\end{array}$ & 03782428 & C & $\begin{array}{l}\text { Probiotics (Lactobacillus, } \\
\text { Bifidobacterium). Placebo }\end{array}$ & $\begin{array}{l}52 \text { patients } \\
\text { Double blinded, randomized } \\
\text { Duration: } 6 \text { months }\end{array}$ & $\begin{array}{l}>18 \text { years old, non-pregnant/nursing, with CRC } \\
\text { planned for resection. No antibiotic or } \\
\text { pro/prebiotic use in past 2-4 weeks }\end{array}$ & $\begin{array}{l}\text { Level of circulating } \\
\text { inflammatory cytokines. } \\
\text { Episodes of } \\
\text { chemo-induced diarrhea. }\end{array}$ & $\begin{array}{l}\text { Decrease in inflammatory cytokines } \\
\text { (ILs) 4w after surgery. Modified } \\
\text { micro-environment }\end{array}$ & Yes \\
\hline $\begin{array}{l}\text { Probiotics in Colorectal Cancer } \\
\text { Patients [146] }\end{array}$ & 00936572 & C & $\begin{array}{l}\text { Probiotics (La1, BB536). } \\
\text { Placebo given twice a day. } \\
\text { Given for } 3 \text { days } \\
\text { preoperatively }\end{array}$ & $\begin{array}{l}31 \text { patients } \\
\text { Triple blinded, randomized } \\
\text { Duration: } 1 \text { year }\end{array}$ & $\begin{array}{l}18-80 \text { years old going for colorectal surgery, } \\
\text { able to provide fecal sample after } \\
\text { pre-operatively. No immunological disorders. }\end{array}$ & $\begin{array}{l}\text { Microbiology of gut flora and } \\
\text { gastrointestinal function }\end{array}$ & $\begin{array}{l}\text { La1 effects intestinal microbiota \& } \\
\text { decreases pathogenic bacterial } \\
\text { concentrations. Little effect } \\
\text { from BB536. }\end{array}$ & Yes \\
\hline $\begin{array}{l}\text { Using Probiotics to Reactivate } \\
\text { Tumor Suppressor Genes in } \\
\text { Colon Cancer [147] }\end{array}$ & 03072641 & C & $\begin{array}{l}\text { ProBion Clinica } \\
\text { (Bifidobacterium, Lactobacillus, } \\
\text { Inulin) }\end{array}$ & $\begin{array}{l}20 \text { participants } \\
\text { Randomized } \\
\text { Duration: } 6 \text { years }\end{array}$ & $\begin{array}{l}\text { 1+ malignant tumor in colon. No recent } \\
\text { antibiotics or probiotics }\end{array}$ & $\begin{array}{l}\text { Microbiology of gut flora } \\
\text { after surgery. Genetic } \\
\text { expression after probiotics. }\end{array}$ & Unknown & No \\
\hline $\begin{array}{l}\text { Prevention of Irinotecan Induced } \\
\text { Diarrhea by Probiotics [148] }\end{array}$ & 01410955 & C & $\begin{array}{l}\text { Probiotics (Colon Dophilus }{ }^{\mathrm{TM}} \text { ). } \\
\text { Placebo }\end{array}$ & $\begin{array}{l}46 \text { patients } \\
\text { Quadruple blinded, } \\
\text { randomized } \\
\text { Duration: } 1 \text { year }\end{array}$ & $\begin{array}{l}\text { Life expectancy }>3 \text { months with CRC (with } \\
\text { irinotecan therapy). No history of ileostomy, no } \\
\text { active infections, no antibiotics }\end{array}$ & Incidence of diarrhea & $\begin{array}{l}\text { Decrease in severe diarrhea episodes } \\
\text { and decrease of diarrhea episodes. } \\
\text { No infections caused by } \\
\text { probiotics observed. }\end{array}$ & Yes \\
\hline $\begin{array}{l}\text { The Effects of Metchnikoff } \\
\text { Probiotics on Symptom and } \\
\text { Surgical Outcome [149] }\end{array}$ & 03531606 & C & $\begin{array}{l}\text { Metchnik-off (Probiotics). } \\
\text { Placebo }\end{array}$ & $\begin{array}{l}68 \text { patients } \\
\text { Randomized } \\
\text { Duration: } 2 \text { years }\end{array}$ & $\begin{array}{l}>20 \text { years old with sigmoid CRC. No metastasis, } \\
\text { no preoperative chemo/radiotherapy. No use of } \\
\text { pre/probiotics in } 7 \text { days }\end{array}$ & $\begin{array}{l}\text { Resection improvement (by } \\
\text { questionnaire) }\end{array}$ & Unknown & No \\
\hline $\begin{array}{l}\text { Synbiotics and Gastrointestinal } \\
\text { Function Related Quality of Life } \\
\text { After Colectomy for Cancer [150] }\end{array}$ & 01479907 & C & $\begin{array}{l}\text { Synbiotics. Placebo } \\
\text { Given postoperative. }\end{array}$ & $\begin{array}{l}100 \text { patients } \\
\text { Quadruple blinded, } \\
\text { Randomized }\end{array}$ & $\begin{array}{l}\text { CRC non-hereditary, non-metastatic. No history } \\
\text { of IBD. Not pregnant patients. }\end{array}$ & $\begin{array}{l}\text { Quality of life related to } \\
\text { GI function' }\end{array}$ & $\begin{array}{l}\text { Better quality of life score over } 3 \\
\text { months. Less episodes of diarrhea. } \\
\text { Non-significant for } \\
\text { constipation episodes. }\end{array}$ & Yes \\
\hline $\begin{array}{l}\text { Gut Mucosal Microbiota is } \\
\text { Associated with Colorectal } \\
\text { Cancer Relapse [151] }\end{array}$ & 03385213 & C & $\begin{array}{l}\text { No intervention post CRC } \\
\text { treatment, including surgery }\end{array}$ & $\begin{array}{l}200 \text { patients } \\
\text { Case Control, retrospective } \\
\text { Completion: December } 2022\end{array}$ & $\begin{array}{l}\text { 18-75 years old, normal weight (BMI 18.5-23.9 } \\
\left.\mathrm{kg} / \mathrm{m}^{2}\right) \text { with CRC. No renal/liver impairment. } \\
\text { No antibiotics or probiotics within } 3 \text { months. } \\
\text { No history of IBD or chronic diarrhea }\end{array}$ & $\begin{array}{l}\text { Microbiology of gut. Genetic } \\
\text { expression changes. }\end{array}$ & Unknown & No \\
\hline $\begin{array}{l}\text { Influence of Sundilac and } \\
\text { Probiotics on the Development } \\
\text { of Pouch Adenomas in Patients } \\
\text { with Familial Adenomatous } \\
\text { Polyposis [152] }\end{array}$ & 00319007 & $\mathrm{U}$ & $\begin{array}{l}\text { Sundilac. Probiotics (VSL \#3). } \\
\text { Prebiotic (Inulin) }\end{array}$ & $\begin{array}{l}30 \text { patients } \\
\text { Randomized } \\
\text { Duration: } 9 \text { months }\end{array}$ & $\begin{array}{l}\text { Proven FAP, restorative proctocolectomy with } \\
\text { ileal pouch anal anastomosis. No renal/liver } \\
\text { impairment, no history of ulcers, no aspirin } \\
\text { within } 3 \text { months. No probiotics }\end{array}$ & Mucosal proliferation & $\begin{array}{l}\text { Non-significant decrease in cell } \\
\text { proliferation in any groups. }\end{array}$ & Yes \\
\hline $\begin{array}{l}\text { The Effects of Probiotics on } \\
\text { Bowel Function Restoration } \\
\text { After Ileostomy Closure in } \\
\text { Patients with Rectal Cancer [153] }\end{array}$ & 02751736 & $\mathrm{U}$ & $\begin{array}{l}\text { Probiotics (CJLP 243). Placebo } \\
\text { Given daily for } 3 \text { weeks before } \\
\text { \& after ileostomy surgery. }\end{array}$ & $\begin{array}{l}40 \text { patients } \\
\text { Quadruple blinded, } \\
\text { randomized } \\
\text { Duration: } 1 \text { year }\end{array}$ & $\begin{array}{l}20-75 \text { years old with CRC lower anterior } \\
\text { resection, non-metastatic. Not pregnant, no } \\
\text { valvular heart disease }\end{array}$ & $\begin{array}{l}\text { Bowel function. MSKCC \& } \\
\text { LARS questionnaire scores. }\end{array}$ & $\begin{array}{l}\text { Non-significant effect on improving } \\
\text { bowel function. } \\
\text { Non-significant use of questionnaires }\end{array}$ & Yes \\
\hline $\begin{array}{l}\text { VSL \#3 Versus Placebo in } \\
\text { Increasing the Pathological } \\
\text { Major Response Rate in Patients } \\
\text { with Rectal Cancer }\end{array}$ & 01579591 & $\mathrm{U}$ & Probiotics (VSL\#3). Placebo & $\begin{array}{l}160 \text { patients } \\
\text { Double blinded, randomized } \\
\text { Duration: } 1 \text { year }\end{array}$ & $\begin{array}{l}>18 \text { years old with CRC, expected to live }>6 \\
\text { months. No antibiotics or probiotics in 1-2 } \\
\text { weeks to registration }\end{array}$ & $\begin{array}{l}\text { TRG1-2 rate. SCFA } \\
\text { expression. Adverse effects. } \\
\text { Immune system changes. }\end{array}$ & Unknown & $\mathrm{u}$ \\
\hline $\begin{array}{l}\text { Intestinal Microflora in } \\
\text { Colorectal Cancer (CRC) After } \\
\text { Chemotherapy }\end{array}$ & 02169388 & $\mathrm{U}$ & $\begin{array}{l}\text { Probiotic (Clostridium } \\
\text { Butyricum). Placebo. Given } \\
\text { twice a day for } 4 \text { weeks. }\end{array}$ & $\begin{array}{l}30 \text { patients } \\
\text { Triple blinded, randomized } \\
\text { Duration: } 4 \text { months }\end{array}$ & $\begin{array}{l}\text { 18-80 years old, non-pregnant/lactating } \\
\text { scheduled for chemotherapy. No renal/liver } \\
\text { impairment. No use of antibiotic or } \\
\text { pre/probiotics for } 1 \text { month }\end{array}$ & $\begin{array}{l}\text { Microbiology and SCFAs in } \\
\text { feces, adverse reactions } \\
\text { during chemotherapy }\end{array}$ & Unknown & $\mathrm{u}$ \\
\hline $\begin{array}{l}\text { Lactobacillus Rhamnous in } \\
\text { Prevention of } \\
\text { Chemotherapy-related } \\
\text { Diarrhea [154] }\end{array}$ & 00197873 & $\mathrm{U}$ & $\begin{array}{l}\text { Probiotic (Lactobacillus } \\
\text { Rhamnosus). Placebo. } \\
\text { During chemotherapy. }\end{array}$ & $\begin{array}{l}84 \text { patients } \\
\text { Quadruple blinded, } \\
\text { Randomized, Cross over } \\
\text { Duration: } 12 \text { years }\end{array}$ & $\begin{array}{l}>18 \text { years old with CRC expected to live }>3 \\
\text { months. No diarrhea, no treatment with } \\
\text { bevacizumab (within } 12 \text { months) }\end{array}$ & $\begin{array}{l}\text { Number of bowel } \\
\text { movements. Chemotherapy } \\
\text { tolerability. }\end{array}$ & Unknown & $\mathrm{u}$ \\
\hline
\end{tabular}

* Status: Unknown (U), Completed (C), Recruiting (R). 
Table 5. Ongoing/recruiting clinical trials for probiotics.

\begin{tabular}{|c|c|c|c|c|c|c|c|}
\hline Study Title & NCT \# & Status * & Intervention & Study & Inclusion/Exclusion Criteria & Outcomes & $\begin{array}{l}\text { Expected End } \\
\text { Date }\end{array}$ \\
\hline $\begin{array}{l}\text { Chemotherapy w/wo WeiLeShu in } \\
\text { Metastatic Colorectal Cancer [155] }\end{array}$ & 04021589 & $\mathrm{R}$ & $\begin{array}{l}\text { Probiotics (WeiLeShu' }{ }^{\mathrm{TM}} \text { from } \\
\text { Tongchuang Biotechnology) with } \\
\text { Chemotherapy }\end{array}$ & $\begin{array}{l}50 \text { patients } \\
\text { Randomized, Open label. Phase II }\end{array}$ & $\begin{array}{l}>18 \text { years old with CRC with good } \\
\text { renal function (creatinine } \\
>2.9 \mathrm{mg} / \mathrm{dl} \text { ) }\end{array}$ & Progression free survival & July 2022 \\
\hline $\begin{array}{l}\text { Prebiotics and Probiotics During } \\
\text { Definitive Treatment with } \\
\text { Chemotherapy-radiotherapy SCC } \\
\text { of the Anal Canal (BISQUIT) [156] }\end{array}$ & 03870607 & $\mathrm{R}$ & Synbiotics. Normal nutrition. & $\begin{array}{l}75 \text { patients } \\
\text { Double blinded, randomized }\end{array}$ & $\begin{array}{l}>18 \text { years old with squamous CRC, } \\
\text { non-metastatic. No infections } \\
\text { requiring antibiotics }\end{array}$ & Response to chemotherapy & February 2024 \\
\hline $\begin{array}{l}\text { Effect of Probiotics } \\
\text { Supplementation on the Side Effects } \\
\text { of Radiation Therapy Among } \\
\text { Colorectal Cancer Patients [157] }\end{array}$ & 03742596 & $\mathrm{R}$ & Probiotics. Placebo & $\begin{array}{l}40 \text { patients } \\
\text { Quadruple blinded, randomized } \\
\text { Phase II }\end{array}$ & $\begin{array}{l}35-65 \text { years old with stage I-III CRC. } \\
\text { No antibiotic or pre/probiotic use } \\
\text { recently. }\end{array}$ & $\begin{array}{l}\text { Level of immunoglobulins } \\
(\mathrm{A}, \mathrm{F}, \mathrm{M}) \text {, interleukins }(6,1, \\
\text { 1), tumor necrosis factor, } \\
\text { C-reactive protein }\end{array}$ & December 2022 \\
\hline $\begin{array}{l}\text { Probiotics as Adjuvant Therapy in } \\
\text { the Treatment of Metastatic } \\
\text { Colorectal Cancer [158] }\end{array}$ & 03705442 & $\mathrm{R}$ & $\begin{array}{l}\text { Omni-Biotic } 10 \text {. Loperamide. } \\
\text { Given twice a day for } 84 \text { days. }\end{array}$ & $\begin{array}{l}76 \text { patients } \\
\text { Assessor blinded, randomized. } \\
\text { Phase II }\end{array}$ & $\begin{array}{l}>18 \text { years old with mitotic CRC } \\
\text { (with FOLFIRI), not terminally ill }(<6 \\
\text { months to live), not using probiotics }\end{array}$ & Incidence of diarrhea & February 2020 \\
\hline
\end{tabular}




\section{Conclusions}

Colorectal cancer is the third most common cancer worldwide. Current treatment options of surgical resection followed by chemotherapy have yet to be perfected or replaced with more targeted therapies. Gaining some understanding on the molecular pathways involved in the initiation and progression of colorectal cancer has been of paramount importance in designing treatment strategies that target certain pathways. Microbial metabolites like short chain fatty acids (SCFAs) have been shown to play pro-apoptotic, anti-proliferation, and anti-cancer roles. Their influence on epigenetics in terms of acting as histone deacetylase inhibitors and the subsequent activation of pro-apoptotic genes can be exploited in such a way that it can be used as primary or adjuvant therapy to current therapies available. Aside from the molecular pathways involved, it is also important to understand the ideal composition of microbiota that would serve to protect against colon cancer. Certain bacteria, like Fusobacterium and Peptostreptococcus, have been shown to be linked to the pathogenesis of colon cancer whereas Lactobacillus and Bifidobacterium have been shown to be cancer protective. Understanding how lifestyle modifications can influence this composition early on and educating the public can be of paramount importance in cutting down the incidence of colorectal cancer. However, more research is needed to provide us with clear-cut evaluations of the anti-carcinogenic, anti-inflammatory, and immunomodulatory properties of probiotics and the exact composition of microbiota that would support a healthy mucosa and maintain immune status to protect against inflammatory processes.

Author Contributions: Conceptualization, R.R.D. and P.L.; Writing—original draft preparation, R.R.D., P.L., M.M., O.A., S.H., H.A., S.U., N.A., T.R., N.L., and B.S.; Writing-review and editing, R.R.D., P.L., M.M., and N.L.; Supervision, R.R.D. All authors approved the final version of the manuscript.

Funding: This research received no external funding.

Conflicts of Interest: Authors declare no conflicts of interest.

\section{References}

1. American Cancer Society. Key Statistics for Colorectal Cancer. Available online: https://www.cancer.org/ cancer/colon-rectal-cancer/about/key-statistics.html (accessed on 27 April 2020).

2. NIH. Cancer Stat Facts: Colorectal Cancer. Available online: https://seer.cancer.gov/statfacts/html/colorect. html (accessed on 1 December 2019).

3. CDC. Colorectal Cancer Statistics. 28 May 2019. Available online: https://www.cdc.gov/cancer/colorectal/ statistics/index.htm (accessed on 1 December 2019).

4. American Cancer Society. Colorectal Cancer Facts and Figures 2017-2019. Available online: https://www.cancer.org/content/dam/cancer-org/research/cancer-facts-and-statistics/colorectal-cancerfacts-and-figures/colorectal-cancer-facts-and-figures-2017-2019.pdf (accessed on 1 December 2019).

5. World Health Organization. Cancers Fact Sheets: Colorectal Cancer. Available online: http://gco.iarc.fr/ today/data/pdf/fact-sheets/cancers/cancer-fact-sheets-6.pdf (accessed on 1 December 2019).

6. Venook, A. Right-Sided vs Left-Sided Colorectal Cancer. Clin. Adv. Hematol. Oncol. 2017, 15, 22-24.

7. Baran, B.; Mert Ozupek, N.; Yerli Tetik, N.; Acar, E.; Bekcioglu, O.; Baskin, Y. Difference Between Left-Sided and Right-Sided Colorectal Cancer: A Focused Review of Literature. Gastroenterol. Res. 2018, 11, $264-273$. [CrossRef] [PubMed]

8. Zou, S.; Fang, L.; Lee, M.H. Dysbiosis of gut microbiota in promoting the development of colorectal cancer. Gastroenterol. Rep. 2018, 6, 1-12. [CrossRef] [PubMed]

9. Purcell, R.V.; Pearson, J.; Aitchison, A.; Dixon, L.; Frizelle, F.A.; Keenan, J.I. Colonization with enterotoxigenic Bacteroides fragilis is associated with early-stage colorectal neoplasia. PLoS ONE 2017, 12, e0171602. [CrossRef] [PubMed]

10. Toprak, N.U.; Yagci, A.; Gulluoglu, B.M.; Akin, M.L.; Demirkalem, P.; Celenk, T.; Soyletir, G. A possible role of Bacteroides fragilis enterotoxin in the etiology of colorectal cancer. Clin. Microbiol. Infect. 2006, 12, 782-786. [CrossRef] [PubMed] 
11. Boleij, A.; Hechenbleikner, E.M.; Goodwin, A.C.; Badani, R.; Stein, E.M.; Lazarev, M.G.; Ellis, B.; Carroll, K.C.; Albesiano, E.; Wick, E.C.; et al. The Bacteroides fragilis toxin gene is prevalent in the colon mucosa of colorectal cancer patients. Clin. Infect. Dis. 2015, 60, 208-215. [CrossRef]

12. Chung, L.; Thiele Orberg, E.; Geis, A.L.; Chan, J.L.; Fu, K.; DeStefano Shields, C.E.; Dejea, C.M.; Fathi, P.; Chen, J.; Finard, B.B.; et al. Bacteroides fragilis Toxin Coordinates a Pro-carcinogenic Inflammatory Cascade via Targeting of Colonic Epithelial Cells. Cell Host Microbe 2018, 23, 203-214. [CrossRef]

13. Lee, Y.K.; Mehrabian, P.; Boyajian, S.; Wu, W.L.; Selicha, J.; Vonderfecht, S.; Mazmanian, S.K. The Protective Role of Bacteroides fragilis in a Murine Model of Colitis-Associated Colorectal Cancer. mSphere 2018, 3, e00587-18. [CrossRef]

14. Abdulamir, A.S.; Hafidh, R.R.; Abu Bakar, F. The association of Streptococcus bovis/gallolyticus with colorectal tumors: The nature and the underlying mechanisms of its etiological role. J. Exp. Clin. Cancer Res. 2011, 30, 11. [CrossRef]

15. Biarc, J.; Nguyen, I.S.; Pini, A.; Gossé, F.; Richert, S.; Thiersé, D.; Van Dorsselaer, A.; Leize-Wagner, E.; Raul, F.; Klein, J.P.; et al. Carcinogenic properties of proteins with pro-inflammatory activity from Streptococcus infantarius (formerly S.bovis). Carcinogenesis 2004, 25, 1477-1484. [CrossRef]

16. Suehiro, Y.; Sakai, K.; Nishioka, M.; Hashimoto, S.; Takami, T.; Higaki, S.; Shindo, Y.; Hazama, S.; Oka, M.; Nagano, H.; et al. Highly sensitive stool DNA testing of Fusobacterium nucleatum as a marker for detection of colorectal tumors in a Japanese population. Ann. Clin. Biochem. 2017, 54, 86-91. [CrossRef] [PubMed]

17. Rubinstei, M.R.; Wang, X.; Liu, W.; Hao, Y.; Cai, G.; Han, Y.W. Fusobacterium nucleatum promotes colorectal carcinogesis by modulating E-cadherin/ $\beta$-catenin signaling via its FadA adhesion. Cell Host Microbe 2013, 14, 195-206. [CrossRef] [PubMed]

18. Cur, C.; Ibrahim, Y.; Isaacson, B.; Yamin, R.; Abed, J.; Gamliel, M.; Enk, J.; Bar-On, Y.; Stanietsky-Kaynan, N.; Coppenhagen-Glazer, S.; et al. Binding of the Fap2 protein of Fusobacterium nucleatum to human inhibitory receptor TIGIT protects tumors from immune cell attack. Immunity 2015, 42, 344-355. [CrossRef]

19. Shang, F.M.; Liu, H.L. Fusobacterium nucleatum and colorectal cancer: A review. World J. Gastrointest. Oncol. 2018, 10, 71-81. [CrossRef]

20. Kelly, D.; Yang, L.; Pei, Z. Gut Microbiota, Fusobacteria, and Colorectal Cancer. Diseases 2018, 6, 109. [CrossRef]

21. Dahmus, J.D.; Kotler, D.L.; Kastenberg, D.M.; Kistler, C.A. The gut microbiome and colorectal cancer: A review of bacterial pathogenesis. J. Gastrointest. Oncol. 2018, 9, 769-777. [CrossRef]

22. Zhong, L.; Zhang, X.; Covasa, M. Emerging roles of lactic acid bacteria in protection against colorectal cancer. World J. Gastroenterol. 2014, 20, 7878-7886. [CrossRef]

23. Wei, H.; Chen, L.; Lian, G.; Yang, J.; Li, F.; Zou, Y.; Lu, F.; Yin, Y. Antitumor Mechanisms of Bifidobacteria. Oncol. Lett. 2018, 16, 3-8. [CrossRef]

24. Ohara, T.; Suzutani, T. Intake of Bifidobacterium longum and Fructo-oligosaccharides prevents Colorectal Carcinogenesis. Euroasian. J. Hepatogastroenterol. 2018, 8, 11-17. [CrossRef]

25. Fahmy, C.A.; Gamal-Eldeen, A.M.; El-Hussieny, E.A.; Raafat, B.M.; Mehanna, N.S.; Talaat, R.M.; Shaaban, M.T. Bifidobacterium longum Suppresses Murine Colorectal Cancer through the Modulation of oncomiRs and Tumor Suppressor miRNAs. Nutr. Cancer 2019, 71, 688-700. [CrossRef]

26. Reddy, B.S.; Rivenson, A. Inhibitory effect of Bifidobacterium longum on colon, mammary, and liver carcinogenesis induced by 2-amino-3-methylimidazo[4,5-f]quinoline, a food mutagen. Cancer Res. 1993, 53, 3914-3918. [PubMed]

27. Hendler, R.; Zhang, Y. Probiotics in the Treatment of Colorectal Cancer. Medicines 2018, 5, 101. [CrossRef] [PubMed]

28. Sivan, A.; Corrales, L.; Hubert, N.; Williams, J.B.; Aquino-Michaels, K.; Earley, Z.M.; Benyamin, F.W.; Lei, Y.M.; Jabri, B.; Alegre, M.L.; et al. Commensal Bifidobacterium promotes antitumor immunity and facilitates anti-PD-L1 efficacy. Science 2015, 350, 1084-1089. [CrossRef] [PubMed]

29. Vetizou, M.; Pitt, J.M.; Daillère, R.; Lepage, P.; Waldschmitt, N.; Flament, C.; Rusakiewicz, S.; Routy, B.; Roberti, M.P.; Duong, C.P.; et al. Anticancer immunotherapy by CTLA-4 blockade relies on the gut microbiota. Science 2015, 350, 1079-1084. [CrossRef]

30. Amersi, F.; Agustin, M.; Ko, C.Y. Colorectal Cancer: Epidemiology, Risk Factors, and Health Services. Clin. Colon Rectal Surg. 2005, 18, 133-140. [CrossRef] 
31. Valle, L. Genetic predisposition to colorectal cancer: Where we stand and future perspectives. World J. Gastroenterol. 2014, 20, 9828-9849. [CrossRef]

32. Haggar, F.A.; Boushey, R.P. Colorectal Cancer Epidemiology: Incidence, Mortality, Survival, and Risk Factors. Clin. Colon Rectal Surg. 2009, 22, 191-197. [CrossRef]

33. Ahsan, H.; Neugut, A.I.; Garbowski, G.C.; Jacobson, J.S.; Forde, K.A.; Treat, M.R.; Waye, J.D. Family history of colorectal adenomatous polyps and increased risk for colorectal cancer. Ann. Int. Med. 1998, 128, 900-905. [CrossRef]

34. Cancer.net. Lynch Syndrome. Available online: https://www.cancer.net/cancer-types/lynch-syndrome (accessed on 27 April 2020).

35. Jang, E.; Chung, D.C. Hereditary Colon Cancer: Lynch Syndrome. Gut Liver 2010, 4, 151-160. [CrossRef]

36. Centers for Disease Control and Prevention. Lynch Syndrome. Available online: https://www.cdc.gov/ genomics/disease/colorectal_cancer/lynch.htm (accessed on 4 November 2019).

37. Jasperson, K.W.; Tuohy, T.M.; Neklason, D.W.; Burt, R.W. Hereditary and Familial Colon Cancer. Gastroenterology 2010, 138, 2044-2058. [CrossRef]

38. Hopkins Medicine. Familial Adenomatous Polyposis. Available online: https:/www.hopkinsmedicine.org/ gastroenterology_hepatology/_pdfs/small_large_intestine/familial_adenomatous_polyposis.pdf(accessed on 4 November 2019).

39. NIH. APC Gene. Available online: https://ghr.nlm.nih.gov/gene/APC (accessed on 4 November 2019).

40. Yang, J.; Zhang, W.; Evans, P.M.; Chen, X.; He, X.; Liu, C. Adenomatous Polyposis Coli (APC) Differentially Regulates $\beta$-Catenin Phosphorylation and Ubiquitination in Colon Cancer Cells. J. Biol. Chem. 2006, 281, 17751-17757. [CrossRef] [PubMed]

41. Anaya, D.A.; Chang, G.J.; Rodriguez-Bigas, M.A. Extracolonic manifestations of hereditary colorectal cancer syndromes. Clin Colon Rectal Surg. 2008, 21, 263-272. [CrossRef] [PubMed]

42. Centers for Disease Control and Prevention. Colorectal (Colon) Cancer. Available online: https://www.cdc. gov/cancer/colorectal/basic_info/screening/index.htm (accessed on 7 November 2019).

43. Larsson, S.C.; Wolk, A. Meat consumption and risk of colorectal cancer: A meta-analysis of prospective studies. Int. J. Cancer 2006, 119, 2657-2664. [CrossRef] [PubMed]

44. Willett, W.C. Diet and cancer: An evolving picture. JAMA 2005, 293, 233-234. [CrossRef] [PubMed]

45. Aune, D.; Chan, D.S.; Lau, R.; Vieira, R.; Greenwood, D.C.; Kampman, E.; Norat, T. Dietary fibre, whole grains, and risk of colorectal cancer: Systematic review and dose-response meta-analysis of prospective studies. BMJ 2011, 343, d6617. [CrossRef]

46. Lee, K.-J.; Inoue, M.; Otani, T.; Iwasaki, M.; Sasazuki, S.; Tsugane, S.; JPHC Study Group. Physical activity and risk of colorectal cancer in Japanese men and women: The Japan Public Health Center-based prospective Study. Cancer Causes Control 2007, 19, 199-209. [CrossRef] [PubMed]

47. Poschl, G.; Seitz, H.K. Alcohol and Cancer. Alcohol Alcoholism 2004, 39, 155-165. [CrossRef]

48. Abdulamir, A.S.; Hafidh, R.R.; Bakar, F.A. Molecular detection, quantification, and isolation of Streptococcus gallolyticus bacteria colonizing colorectal tumors: Inflammation-driven potential of carcinogenesis via IL-1, COX-2, and IL-8. Mol Cancer 2010, 9, 249. [CrossRef]

49. Pericas, J.M.; Corredoira, J.; Moreno, A.; García-País, M.J.; Falces, C.; Rabuñal, R.; Mestres, C.A.; Alonso, M.P.; Marco, F.; Quintana, E.; et al. Relationship Between Enterococcus faecalis Infective Endocarditis and Colorectal Neoplasm: Preliminary Results from a Cohort of 154 Patients. Rev. Esp. Cardiol. (Engl. Ed.) 2017, 70, 451-458. [CrossRef]

50. Cuevas-Ramos, G.; Petit, C.R.; Marcq, I.; Boury, M.; Oswald, E.; Nougayrède, J.P. Escheria coli induces DNA damage in vivo and triggers genomic instability in mammalian cells. Proc. Natl. Aca. Sci. USA 2010, 107, 11437-11542. [CrossRef]

51. Pleguezuelos-Manzano, C.; Puschhof, J.; Huber, A.R.; van Hoeck, A.; Wood, H.M.; Nomburg, J.; Gurjao, C.; Manders, F.; Dalmasso, G.; Stege, P.B.; et al. Mutational signature in colorectal cancer caused by genotoxic pks+ E.coli. Nature 2020. [CrossRef] [PubMed]

52. Raisch, J.; Rolhion, N.; Dubois, A.; Darfeuille-Michaud, A.; Bringer, M.A. Intracellular colon cancer-associated Escherichia coli promote protumoral activities of human macrophages by inducing sustained COX-2 expression. Lab. Investig. 2015, 95, 296-307. [CrossRef] [PubMed] 
53. Chang, J.H.; Shim, C.; Cha, S.K.; Reaney, M.; Mahn Chee, K. Effect of Lactobacillus acidophilus KFRI34 on the development of chemically induced precancerous growths in the rat colon. J. Med. Microbiol. 2012, 61, 361-368. [CrossRef] [PubMed]

54. Agah, S.; Alizadeh, A.M.; Mosavi, M.; Ranji, P.; Khavari-Daneshvar, H.; Ghasemian, F.; Bahmani, S.; Tavassoli, A. More Protection of Lactobacillus acidophilus Than Bifidobacterium bifidum Probiotics on Azoxymethane-Induced Mouse Colon Cancer. Probiotics Antimicrob. Protein. 2019, 11, 857-864. [CrossRef]

55. Zhu, J.; Zhu, C.; Ge, S.; Zhang, M.; Jiang, L.; Cui, J.; Ren, F. Lactobacillus salivarius Ren prevent the early colorectal carcinogenesis in 1,2-dimethylhydrazine-induced rate model. J. Appl. Microbiol. 2014, 117, 208-216. [CrossRef]

56. Zhang, M.; Fan, X.; Fang, B.; Zhu, C.; Zhu, J.; Ren, F. Effects of Lactobacillus salivarius Ren on cancer prevention and intestinal microbiota in 1, 2-dimethylhydrazine-induced rat model. J. Microbiol. 2015, 53, 398-405. [CrossRef]

57. Sittipo, P.; Lobionda, S.; Choi, K.; Sari, I.N.; Kwon, H.Y.; Lee, Y.K. Toll-Like Receptor 2-Mediated Suppression of Colorectal Cancer Pathogenesis by Polysaccharide A from Bacteroides fragilis. Front. Microbiol. 2018, 9 , 1588. [CrossRef]

58. Chen, Z.F.; Al, L.Y.; Wang, J.L.; Ren, L.L.; Yu, Y.N.; Xu, J.; Chen, H.Y.; Yu, J.; Li, M.; Qin, W.X.; et al. Probiotics Clostridium butyridium and Bacillus subtilis ameliorate intestinal tumorigenesis. Future Microbiol. 2015, 10, 1433-1445. [CrossRef]

59. Chen, D.; Jin, D.; Huang, S.; Wu, J.; Xu, M.; Liu, T.; Dong, W.; Liu, X.; Wang, S.; Zhong, W.; et al. Clostridium butyricum, a butyrate-producing probiotic, inhibits intestinal humor development through modulating Wnt signaling and gut microbiota. Cancer Lett. 2020, 469, 456-467. [CrossRef]

60. Xie, Z.; Qu, Y.; Leng, Y.; Sun, W.; Ma, S.; Wei, J.; Hu, J.; Zhang, X. Human Colon Carcinogenesis is Associated with Increased Interleukin-17 Driven Inflammatory Responses. Drug Des. Devel. Ther. 2015, 9, 1679-1689. [CrossRef]

61. Wu, S.; Rhee, K.J.; Albesiano, E.; Rabizadeh, S.; Wu, X.; Yen, H.R.; Huso, D.L.; Brancati, F.L.; Wick, E.; McAllister, F.; et al. A human colonic commensal promotes colon tumorigenesis via activation of T helper type 17 T cell responses. Nat. Med. 2009, 15, 1016-1022. [CrossRef] [PubMed]

62. Lin, W.-W.; Karin, M. A cytokine-mediated link between innate immunity, inflammation, and cancer. J. Clin. Invest. 2007, 117, 1175-1183. [CrossRef] [PubMed]

63. Mirsepasi-Lauridsen, H.C.; Vallance, B.A.; Krogfelt, K.A.; Petersen, A.M. Escherichia coli pathobionts associated with inflammatory bowel disease. Clin. Microbiol. Rev. 2019, 32, e00060-18. [CrossRef] [PubMed]

64. Yang, Y.; Jobin, C. Microbial imbalance and intestinal pathologies: Connections and contributions. Dis. Model Mech. 2014, 7, 1131-1142. [CrossRef] [PubMed]

65. Langowski, J.; Zhang, X.; Wu, L.; Mattson, J.D.; Chen, T.; Smith, K.; Basham, B.; McClanahan, T.; Kastelein, R.A.; Oft, M. IL-23 promotes tumor incidence and growth. Nature 2006, 442, 461-465. [CrossRef] [PubMed]

66. Hardy, H.; Harris, J.; Lyon, E.; Beal, J.; Foey, A.D. Probiotics, prebiotics and immunomodulation of gut mucosal defenses: Homeostasis and immunopathology. Nutrients 2013, 5, 1869-1912. [CrossRef]

67. Meng, C.; Bai, C.; Brown, T.D.; Hood, L.E.; Tian, Q. Human Gut Microbiota and Gastrointestinal Cancer. Genomics Proteomics Bioinforma. 2018, 16, 33-49. [CrossRef]

68. Bellam, N.; Pasche, B. Tgf-beta signaling alterations and colon cancer. Cancer Treats Res. 2010, 155, 85-103. [CrossRef]

69. Villalba, M.; Evans, S.R.; Vidal-Vanaclocha, F.; Calvo, A. Role of TGF- $\beta$ in metastatic colon cancer: It is finally time for targeted therapy. Cell Tissue Res. 2017, 370, 29-39. [CrossRef]

70. Calon, A.; Espinet, E.; Palomo-Ponce, S.; Tauriello, D.V.; Iglesias, M.; Céspedes, M.V.; Sevillano, M.; Nadal, C.; Jung, P.; Zhang, X.H.; et al. Dependency of colorectal cancer on a TGF-beta-driven program in stromal cells for metastasis initiation. Cancer Cell. 2012, 22, 571-584. [CrossRef]

71. Bauche, D.; Marie, J.C. Transforming growth factor $\beta$ : A master regulator of the gut microbiota and immune cell interactions. Clin. Trans. Immunol. 2017, 6, e136. [CrossRef] [PubMed]

72. Haque, S.; Morris, J. Transforming Growth Factor-beta: A Therapeutic Target for Cancer. Hum. Vaccines Immunother. 2017, 13, 1741-1750. [CrossRef] [PubMed] 
73. Stamatakis, K.; Jimenez-Martinez, M.; Jimenez-Segovia, A.; Chico-Calero, I.; Conde, E.; Galán-Martínez, J.; Ruiz, J.; Pascual, A.; Barrocal, B.; López-Pérez, R.; et al. Prostaglandins induce early growth response 1 transcription factor mediated microsomal prostaglandin E2 synthase up-regulation for colorectal cancer progression. Oncotarget 2015, 6, 39941-39959. [CrossRef] [PubMed]

74. Makar, K.W.; Poole, E.M.; Resler, A.J.; Seufert, B.; Curtin, K.; Kleinstein, S.E.; Duggan, D.; Kulmacz, R.J.; Hsu, L.; Whitton, J.; et al. COX-1 (PTGS1) and COX-2 (PTGS2) Polymorphisms, NSAID Interactions, and Risk of Colon and Rectal Cancer in Two Independent Populations. Cancer Causes Control 2013, 24, 2059-2075. [CrossRef]

75. Sanz-Garcia, E.; Argiles, G.; Tabernero, E.; Tabernero, J. BRAF mutation colorectal cancer: Prognosis, treatment, and new perspectives. Ann. Oncol. 2017, 28, 2648-2657. [CrossRef]

76. Leicht, D.T.; Balan, V.; Kaplun, A.; Singh-Gupta, V.; Kaplun, L.; Dobson, M.; Tzivion, G. Raf Kinases: Function, Regulation, and Role in Human Cancer. Biochimica et Biophysica Acta (BBA)-Molecular Cell Research 2007, 1773, 1196-1212. [CrossRef]

77. Shibuya, M. Vascular endothelial growth factor (VEGF) and its receptor (VEGFR) signaling in angiogenesis: A crucial target for anti- and pro-angiogenic therapies. Genes Cancer. 2011, 2, 1097-1105. [CrossRef]

78. Cane, G.; Moal, V.L.; Pagès, G.; Servin, A.L.; Hofman, P.; Vouret-Craviari, V. Up-regulation of intestinal vascular endothelial growth factor by Afa/Dr diffusely adhering Escherichia coli. PLoS ONE 2007, 2, e1359. [CrossRef]

79. Bhattacharya, R.; Fan, F.; Wang, R.; Ye, X.; Xia, L.; Boulbes, D.; Ellis, L.M. Intracrine VEGF Signaling Mediates Colorectal Cancer Cell Migration and Invasion. Br. J. Cancer 2017, 117, 848-855. [CrossRef]

80. Schirbel, A.; Kessler, S.; Rieder, F.; West, G.; Rebert, N.; Asosingh, K.; McDonald, C.; Fiocchi, C. Pro-angiogenic activity of TLRs and NLRs: A novel link between gut microbiota and intestinal angiogenesis. Gastroenterology 2013, 144, 613-623. [CrossRef]

81. Yi, W.; Xiao, E.; Ding, R.; Luo, P.; Yang, Y. High Expression of Fibronectin is Associated with Poor Prognosis, Cell Proliferation and Malignancy via the NF-kB/p53-Apoptosis Signaling Pathway in Colorectal Cancer. Oncol. Rep. 2016, 36, 3145-3153. [CrossRef] [PubMed]

82. Wang, J.; Hielscher, A. Fibronectin: How Its Aberrant Expression in Tumors May Improve Therapeutic Targeting. J. Cancer 2017, 8, 674-682. [CrossRef] [PubMed]

83. Jahani-Sherafat, S.; Somayeh, M.; Moghim, S.; Ahmadi Amoli, H.; Ghasemian-Safaei, H. Role of gut microbiota in the pathogenesis of colorectal cancer; a review article. Gastroenterol. Hepatol. Bed Bench 2018, 11, 101-109. [PubMed]

84. NIH. Cancer Staging. Available online: https://www.cancer.gov/about-cancer/diagnosis-staging/staging (accessed on 5 November 2019).

85. NCCN Guidelines for Patients. Colon Cancer. 2018. Available online: https://www.nccn.org/patients/ guidelines/colon/files/assets/common/downloads/files/colon.pdf (accessed on 5 November 2019).

86. Danenberg, P.V.; Malli, H.; Swenson, S. Thymidylate synthase inhibitors. Semin Oncol. 1999, 26, 621-631. [PubMed]

87. Saif, M.W.; Makrilia, N.; Syrigos, K. CoFactor: Folate requirement for optimization of 5-fluouracil activity in anticancer chemotherapy. J. Oncol. 2010, 2010, 934359. [CrossRef]

88. Drugs Approved for Colon and Rectal Cancer. National Cancer Institute. Available online: https: //www.cancer.gov/about-cancer/treatment/drugs/colorectal. (accessed on 27 April 2020).

89. Syed, Y.Y.; McKeage, K. Aflibercept: A review in metastatic colorectal cancer. Drugs 2015, 75, 1435-1445. [CrossRef]

90. Jaiswal, P.; Goel, A.; Mittal, R.D. Survivin: A Molecular Biomarker in Cancer. Indian J. Med. Res. 2015, 141, 389-397. [CrossRef]

91. Tukenmez, U.; Aktas, B.; Aslim, B.; Yavuz, S. The Relationship Between the Structural Characteristics of Lactobacilli-EPS and Its Ability to Induce Apoptosis in Colon Cancer Cells in vitro. Sci. Rep. 2019, 9, 8268. [CrossRef]

92. Ding, L.; Lan, Z.; Xiong, X.; Ao, H.; Feng, Y.; Gu, H.; Yu, M.; Cui, Q. The Dual Role of MicroRNAs in Colorectal Cancer Progression. Int. J. Mol. Sci. 2018, 19, 2791. [CrossRef]

93. Masuda, T.; Hayashi, N.; Kuroda, Y.; Ito, S.; Eguchi, H.; Mimori, K. MicroRNAs as Biomarkers in Colorectal Cancer. Cancers 2017, 9, 124. [CrossRef] 
94. Stattin, P.; Lukanova, A.; Biessy, C.; Soderberg, S.; Palmqvist, R.; Kaaks, R.; Olsson, T.; Jellum, E. Obesity and colon cancer: Does leptin provide a link? Int. J. Cancer 2004, 109, 149-152. [CrossRef] [PubMed]

95. Ranji, P.; Agah, S.; Heydari, Z.; Rahmati-yamchi, M.; Mohammad Alizadeh, A. Effects of Lactobacillus acidophilus and Bifidobacterium bifidum probiotics on the serum biochemical parameters, and the vitamin D and leptin receptor genes on mice colon cancer. Iran. J. Basic Med. Sci. 2019, 22, 631-636. [CrossRef] [PubMed]

96. Richman, S. Deficient mismatch repair: Read all about it (Review). Int. J. Oncol. 2015, 47, 1189-1202. [CrossRef] [PubMed]

97. Hong, D.S.; Bauer, T.M.; Lee, J.J.; Dowlati, A.; Brose, M.S.; Farago, A.F.; Taylor, M.; Shaw, A.T.; Montez, S.; Meric-Bernstam, F.; et al. Larotrectinib in adult patients with solid tumours: A multi-center, open-label, phase I dose-escalation study. Ann. Oncol. 2019, 30, 325-331. [CrossRef]

98. Stenger, M. Larotrectinib for Solid Tumors with NTRK Gene Fusions. ASCO Post. Available online: https:/www.ascopost.com/issues/december-25-2018/larotrectinib-for-solid-tumors-withntrk-gene-fusions/ (accessed on 22 November 2019).

99. FDA. FDA Approves Larotrectinib for Solid Tumors with NTRK Gene Fusions. 26 November 2018. Available online: https:/www.fda.gov/drugs/fda-approves-larotrectinib-solid-tumors-ntrk-gene-fusions-0 (accessed on 6 December 2019).

100. Drilon, A.; Laetsch, T.W.; Kummar, S.; DuBois, S.G.; Lassen, U.N.; Demetri, G.D.; Nathenson, M.; Doebele, R.C.; Farago, A.F.; Pappo, A.S.; et al. Efficacy of larotrectinib in trk fusion-positive cancers in adults and children. N. Engl. J. Med. 2018, 378, 731-739. [CrossRef]

101. Edwards, M.S.; Chadda, S.D.; Zhao, Z.; Barber, B.L.; Sykes, D.P. A systematic review of treatment guidelines for metastatic colorectal cancer. Colorectal Dis. 2012, 14, e31-e47. [CrossRef]

102. Caffrey, M. New Nccn Crc Guidelines include Updates in Testing, Treatment Options. Targeted Oncology. 25 March 2019. Available online: https://www.targetedonc.com/news/new-nccn-crc-guidelines-includeupdates-in-testing-treatment-options (accessed on 6 December 2019).

103. Food and Agriculture Organization of the United Nations. Probiotics in Food. Available online: http: //www.fao.org/3/a-a0512e.pdf (accessed on 22 April 2020).

104. Zhu, B.; Wang, X.; Li, L. Human gut microbiome: The second genome of human body. Protein Cell 2010, 1, 718-725. [CrossRef]

105. Mueller, N.T.; Bakacs, E.; Combellick, J.; Grigoryan, Z.; Dominguez-Bello, M.G. The Infant Microbiome Development: Mom Matters. Trends Mol. Med. 2015, 21, 109-117. [CrossRef]

106. Rapozo, D.C.M.; Bernardazzi, C.; de Souza, H.S.P. Diet and microbiota in inflammatory bowel disease: The gut in disharmony. World J. Gastroenterol. 2017, 23, 2124-2140. [CrossRef]

107. Sivamaruthi, B.S.; Kesika, P.; Chaiyasut, C. The Role of Probiotics in Colorectal Cancer Management. Evid Based Complement Alternat Med. 2020, 2020, 3535982. [CrossRef]

108. Hibberd, A.A.; Lyra, A.; Ouwehand, A.C.; Rolny, P.; Lindegren, H.; Cedgård, L.; Wettergren, Y. Intestinal microbiota is altered in patients with colon cancer and modified by probiotic intervention. BMJ Open Gastroenterol. 2017, 4, e0000145. [CrossRef] [PubMed]

109. Gogineni, V.K.; Morrow, L.E.; Malesker, M.A. Probiotics: Mechanisms of action and clinical applications. J. Probiotics Health 2013, 1, 2. [CrossRef]

110. Bermudez-Brito, M.; Plaza-Díaz, J.; Muñoz-Quezada, S.; Gómez-Llorente, C.; Gil, A. Probiotic mechanisms of action. Ann. Nutr. Metab. 2012, 61, 106-174. [CrossRef] [PubMed]

111. Yuan, L.; Zhang, S.; Li, H.; Yang, F.; Mushtaq, N.; Ullah, S.; Shi, Y.; An, C.; Xu, J. The influence of gut microbiota dysbiosis to the efficacy of 5-fluorouracil treatment on colorectal cancer. Sci. Direct. 2018, 108, 184-193. [CrossRef]

112. Carding, S.; Verbeke, K.; Vipond, D.T.; Corfe, B.M.; Owen, L.J. Dysbiosis of the Gut Microbiota in Disease. Microb. Ecol. Healthy Dis. 2015, 26, 26191. [CrossRef]

113. Walker, A.; Lawley, T. Therapeutic modulation of intestinal dysbiosis. Pharmacol. Res. 2013, 69, 75-86. [CrossRef]

114. Weir, T.L.; Manter, D.K.; Sheflin, A.M.; Barnett, B.A.; Heuberger, A.L.; Ryan, E.P. Stool Microbiome and Metabolome Differences between Colorectal Cancer Patients and Healthy Adults. PLoS ONE 2013, 8, e70803. [CrossRef] 
115. Gao, Z.; Guo, B.; Gao, R.; Zhu, Q.; Wu, W.; Qin, H. Probiotics modify human intestinal mucosa-associated microbiota in patients with colorectal cancer. Mol. Med. Rep. 2015, 12, 6119-6127. [CrossRef]

116. Isolauri, E.; Salminen, S.; Ouwehand, A. Probiotics. Best Pract. Res. Clin. Gastroenterol. 2004, 8, $299-313$. [CrossRef]

117. Zhou, S.; Chen, J.; Yao, H.; Hu, H. Fusobacterium and Colorectal Cancer. Front. Oncol. 2018, 8, 371. [CrossRef]

118. Haghi, F.; Goli, E.; Mirzaei, B.; Zeighami, H. The association between fecal enterotoxigenic B. fragilis with colorectal cancer. BMC Cancer 2019, 19, 879. [CrossRef] [PubMed]

119. Raisch, J.; Buc, E.; Bonnet, M.; Sauvanet, P.; Vazeille, E.; de Vallée, A.; Déchelotte, P.; Darcha, C.; Pezet, D.; Bonnet, R.; et al. Colon Cancer-Associated B2 Escherichia Coli Colonize Gut Mucosa and Promote Cell Proliferation. World J. Gastroenterol. 2014, 20, 6560-6572. [CrossRef] [PubMed]

120. Ghosh, T.; Beniwal, A.; Semwal, A.; Navani, N.K. Mechanistic Insights into Probiotic Properties of Lactic Acid Bacteria Associated with Ethnic Fermented Dairy Products. Front. Microbiol. 2019, 10, 502. [CrossRef] [PubMed]

121. Edwards, C.A. GUMS | Dietary Importance, 2nd ed.; Encyclopedia of Food Sciences and Nutrition; Academic Press: Cambridge, MA, USA, 2003; pp. 3007-3012. [CrossRef]

122. McNabney, S.; Henagan, T. Short Chain Fatty Acids in the Colon and Peripheral Tissues: A Focus on Butyrate, Colon Cancer, Obesity and Insulin Resistance. Nutrients 2017, 9, 1348. [CrossRef]

123. Eckschlager, T.; Plch, J.; Stiborova, M.; Hrabeta, J. Histone Deacetylase Inhibitors as Anticancer Drugs. Int. J. Mol. Sci. 2017, 18, 1414. [CrossRef] [PubMed]

124. Daroqui, M.C.; Augenlicht, L.H. Transcriptional attenuation in colon carcinoma cells in response to butyrate. Cancer Prev. Res. (Phila) 2010, 3, 1292-1302. [CrossRef] [PubMed]

125. Alao, J. The regulation of cyclin D1 degradation: Roles in cancer development and the potential for therapeutic invention. Mol. Cancer 2007, 6, 24. [CrossRef]

126. Lee, J.H.; Choy, M.L.; Ngo, L.; Foster, S.S.; Marks, P.A. Histone deacetylase inhibitor induces DNA damage, which normal but not transformed cells can repair. Proc. Natl. Acad. Sci. USA 2010, 2010 107, 14639-14644. [CrossRef]

127. Yuille, S.; Reichardt, N.; Panda, S.; Dunbar, H.; Mulder, I.E. Human gut bacteria as potent class I histone deacetylase inhibitors in vitro through production of butyric acid and valeric acid. PLOS ONE 2018, 13, e0201073. [CrossRef]

128. Cornick, S.; Tawiah, A.; Chadee, K. Roles and Regulation of the Mucus Barrier in the Gut. Tissue Barriers 2015, 3, e982426. [CrossRef]

129. Molska, M.; Reguła, J. Potential mechanisms of probiotics action in the prevention and treatment of colorectal cancer. Nutrients 2019, 11, 2453. [CrossRef] [PubMed]

130. Kho, Z.; Lal, S. The Human Gut Microbiome-A Potential Controller of Wellness and Disease. Front. Microbiol. 2018, 9, 1835. [CrossRef] [PubMed]

131. Gosai, V.; Ambalam, P.; Raman, M.; Kothari, C.R.; Kothari, R.K.; Vyas, B.R.; Sheth, N.R. Protective Effect of Lactobacillus rhamnosus 231 Against N-Methyl-N'-Nitro-N-Nitrosoguanidine in Animal Model. Gut Microbes 2011, 2, 319-325. [CrossRef] [PubMed]

132. De Almeida, C.V.; de Camargo, M.R.; Russo, E.; Amedei, A. Role of diet and gut microbiota on colorectal cancer immunomodulation. World J Gastroenterol. 2019, 25, 151-162. [CrossRef]

133. Azad, A.; Sarker, M.; Wan, D. Immunomodulatory Effects of Probiotics on Cytokine Profiles. BioMed Res. Inte. 2018, 2018, 1-10. [CrossRef]

134. Ohigashi, S.; Sudo, K.; Kobayashi, D.; Takahashi, O.; Takahashi, T.; Asahara, T.; Nomoto, K.; Onodera, H. Changes of the Intestinal Microbiota, Short Chain Fatty Acids, and Fecal pH in Patients with Colorectal Cancer. Dig. Dis. Sci. 2013, 58, 1717-1726. [CrossRef]

135. Norouzi, Z.; Salimi, A.; Halabian, R.; Fahimi, H. Nisin, a potent bacteriocin and anti-bacterial peptide, attenuates expression of metastatic genes in colorectal cancer cell lines. Microbial pathogenesis. 2018, 123, 183-189. [CrossRef]

136. Probiotics. National Institutes of Health. 26 June 2019. Available online: https://ods.od.nih.gov/factsheets/ Probiotics-HealthProfessional/ (accessed on 6 December 2019).

137. Bourrie, B.; Willing, B.; Cotter, P. The Microbiota and Health Promoting Characteristics of the Fermented Beverage Kefir. Front. Microbiol. 2016, 7, 647. [CrossRef] 
138. Sharifi, M.; Moridnia, A.; Mortazavi, D.; Salehi, M. Kefir: A powerful probiotics with anticancer properties. Med. Oncol. 2017, 34, 183-189. [CrossRef]

139. Leedy, R. As Probiotics Use Grows for Gut Health, Vsl\#3 Has Designations for Specific Gi Issues Eurekaalert! Available online: https://www.eurekalert.org/pub_releases/2011-11/rla-apu111711.php (accessed on 18 November 2011).

140. Appleyard, C.B.; Cruz, M.L.; Isidro, A.A.; Arthur, J.C.; Jobin, C.; De Simone, C. Pretreatment with the probiotic vsl\#3 delays transition from inflammation to dysplasia in a rat model of colitis-associated cancer. Am. J. Phyiol. Gastrointest. Liver Physiol. 2011, 301, G1004-G1013. [CrossRef]

141. Arthur, J.C.; Raad, Z.; Gharaibeh, R.Z.; Uronis, J.M.; Perez-Chanona, E.; Sha, W.; Tomkovich, S.; Mühlbauer, M.; Fodor, A.A.; Jobin, C. VSL\#3 Probiotic Modifies Mucosal Microbial Composition but does not Reduce Colitis-Associated Colorectal Cancer. Sci. Rep. 2013, 3, 2868. [CrossRef] [PubMed]

142. Wilkins, S. Probiotics for gastrointestinal conditions: A summary of the evidence. Am. Fam. Physician 2017, 96, 170-178. [PubMed]

143. Gossard, C.M.; Pizano, J.M.; Burns, C.M.; Williamson, C.B.; Dolan, K.E.; Finley, H.J.; Gasta, M.G.; Parker, E.C.; Lipski, E.A. Probiotics and Disease: A Comprehensive Summary-Part 9, Cancer. Integr. Med. (Encinitas) 2018, 17, 34-46. [PubMed]

144. Jiang, T.; Zhou, C.; Ren, S. Role of IL-2 in Cancer Immunotherapy. OncoImmunology 2016, 5, e1163462. [CrossRef]

145. Zaharauddin, L.; Mokhtar, N.M.; Muhammad Nawawi, K.N.; Raja Ali, R.A. A randomized double-blind placebo-controlled trial of probiotics in post-surgical colorectal cancer. BMC Gastroenterol. 2019, 19, 131. [CrossRef]

146. Gianotti, L.; Morelli, L.; Galbiati, F.; Rocchetti, S.; Coppola, S.; Beneduce, A.; Gilardini, C.; Zonenschain, D.; Nespoli, A.; Braga, M. A randomized double-blind trial on perioperative administration of probiotics in colorectal cancer patients. World J. Gastroenterol. 2010, 16, 167-175. [CrossRef]

147. Vastra Gotaland Region. Using Probiotics to Reactivate Tumor Suppressor Genes in Colon Cancer. NIH. Available online: https://clinicaltrials.gov/ct2/show/NCT03072641 (accessed on 28 November 2019).

148. Mego, M.; Chovanec, J.; Vochyanova-Andrezalova, I.; Konkolovsky, P.; Mikulova, M.; Reckova, M.; Miskovska, V.; Bystricky, B.; Beniak, J.; Medvecova, L.; et al. Prevention of irinotecan induced diarrhea by probiotics: A randomized double blind, placebo-controlled pilot study. Complement. Ther. Med. 2015, 23, 356-362. [CrossRef]

149. Bong-Hyeon, K. The Effects of Mechnikov Probiotics on Symptom and Surgical Outcome. NIH. Available online: https://clinicaltrials.gov/ct2/show/NCT03531606 (accessed on 3 December 2019).

150. Theodorophoulos, G.E.; Memos, N.A.; Peitsidou, K.; Karantanos, T.; Spyropoulos, B.G.; Zografos, G. Synbiotics and gastrointestinal function-related quality of life after elective colorectal cancer resection. Ann. Gastroenterol. 2016, 29, 56-62.

151. First Affiliated Hospital of Harbin Medical University. Gut Mucosal Microbiota is Associated with Colorectal Cancer Relapse. NIH. Available online: https://clinicaltrials.gov/ct2/show/NCT03385213 (accessed on 3 January 2020).

152. Friederich, P.; Verschuur, J.; van Heumen, B.W.; Roelofs, H.M.; Berkhout, M.; Nagtegaal, I.D.; van Oijen, M.G.; van Krieken, J.H.; Peters, W.H.; Nagengast, F.M. Effects of intervention with sulindac and inulin/VSL\#3 on mucosal and luminal factors in the pouch of patients with familial adenomatous polyposis. Int. J. Colorectal. Dis. 2011, 26, 575-582. [CrossRef]

153. Cho, J.R.; Yoon, B.; Oh, H.K. Effect of Probiotics on Bowel Function Restoration After Ileostomy Reversal in Patients with Rectal Cancer: A Double-Blind Randomized Controlled Trial. Gastroenterology 2019, 156, S1421. [CrossRef]

154. Helsinki University. Lactobacillus Rhamnosus in Prevention of Chemotherapy-related Diarrhea. NIH. Available online: https:/clinicaltrials.gov/ct2/show/NCT00197873 (accessed on 6 December 2019).

155. Zhejiang University. Chemotherapy w/wo WeiLeShu in Metastatic Colorectal Cancer. NIH. Available online: https://clinicaltrials.gov/ct2/show/NCT04021589 (accessed on 6 December 2019).

156. AC Camargo Cancer Center. Prebiotics and Probiotics During Definitive Treatment with Chemotherapy-radiotherapy SCC of the Anal Canal (BISQUIT). NIH. Updated November 2018. Available online: https://clinicaltrials.gov/ct2/show/NCT03870607 (accessed on 3 January 2020). 
157. King Hussein Cancer Center. Effect of Probiotics Supplementation on the Side Effects of Radiation Therapy Among Colorectal Cancer Patients. NIH. Updated January 2020. Available online: https: //clinicaltrials.gov/ct2/show/NCT03742596 (accessed on 3 January 2020).

158. Golcic, M. Probiotics as Adjuvant Therapy in the Treatment of Metastatic Colorectal Cancer (Probat-tmccc-17). NIH. Updated October 218. Available online: https://clinicaltrials.gov/ct2/show/NCT03705442 (accessed on 3 January 2020).

(c) (4)

(C) 2020 by the authors. Licensee MDPI, Basel, Switzerland. This article is an open access article distributed under the terms and conditions of the Creative Commons Attribution (CC BY) license (http://creativecommons.org/licenses/by/4.0/). 